NBER WORKING PAPER SERIES

\title{
CAN SUCCESSFUL SCHOOLS REPLICATE? SCALING UP BOSTON'S CHARTER SCHOOL SECTOR
}

\author{
Sarah Cohodes \\ Elizabeth Setren \\ Christopher R. Walters \\ Working Paper 25796 \\ http://www.nber.org/papers/w25796
NATIONAL BUREAU OF ECONOMIC RESEARCH
1050 Massachusetts Avenue
Cambridge, MA 02138
May 2019

Special thanks go to Carrie Conaway, Cliff Chuang, the staff of the Massachusetts Department of Elementary and Secondary Education, and Boston's charter schools for data and assistance. We also thank Josh Angrist, Bob Gibbons, Caroline Hoxby, Parag Pathak, Derek Neal, Eric Taylor and seminar participants at the NBER Education Program Meetings, Columbia Teachers College Economics of Education workshop, the Association for Education Finance and Policy Conference, the Society for Research on Educational Effectiveness Conference, Harvard Graduate School of Education, Federal Reserve Bank of New York, MIT Organizational Economics Lunch, MIT Labor Lunch, and University of Michigan Causal Inference for Education Research Seminar for helpful comments. We are grateful to the school leaders who shared their experiences expanding their charter networks: Shane Dunn, Jon Clark, Will Austin, Anna Hall, and Dana Lehman. Setren was supported by a National Science Foundation Graduate Research Fellowship. The Massachusetts Department of Elementary and Secondary Education had the right to review this paper prior to circulation in order to determine no individual's data was disclosed. The authors obtained Institutional Review Board (IRB) approvals for this project from NBER and Teachers College Columbia University. The views expressed herein are those of the authors and do not necessarily reflect the views of the National Bureau of Economic Research.

NBER working papers are circulated for discussion and comment purposes. They have not been peer-reviewed or been subject to the review by the NBER Board of Directors that accompanies official NBER publications.

(C) 2019 by Sarah Cohodes, Elizabeth Setren, and Christopher R. Walters. All rights reserved. Short sections of text, not to exceed two paragraphs, may be quoted without explicit permission provided that full credit, including $\odot$ notice, is given to the source. 
Can Successful Schools Replicate? Scaling Up Boston's Charter School Sector

Sarah Cohodes, Elizabeth Setren, and Christopher R. Walters

NBER Working Paper No. 25796

May 2019

JEL No. H75,I21,I28

\author{
$\underline{\text { ABSTRACT }}$ \\ Can schools that boost student outcomes reproduce their success at new campuses? We study a \\ policy reform that allowed effective charter schools in Boston, Massachusetts to replicate their \\ school models at new locations. Estimates based on randomized admission lotteries show that \\ replication charter schools generate large achievement gains on par with those produced by their \\ parent campuses. The average effectiveness of Boston's charter middle school sector increased \\ after the reform despite a doubling of charter market share. An exploration of mechanisms shows \\ that Boston charter schools reduce the returns to teacher experience and compress the distribution \\ of teacher effectiveness, suggesting the highly standardized practices in place at charter schools \\ may facilitate replicability. \\ Sarah Cohodes \\ Teachers College \\ Columbia University \\ 525 West 120th Street \\ New York, NY 10027 \\ and NBER \\ cohodes@tc.columbia.edu \\ Elizabeth Setren \\ 8 Upper Campus Road \\ Braker Hall \\ Tufts University \\ Medford, MA 02155 \\ United States \\ elizabeth.setren@tufts.edu \\ Christopher R. Walters \\ Department of Economics \\ University of California, Berkeley \\ 530 Evans Hall \#3880 \\ Berkeley, CA 94720-3880 \\ and NBER \\ crwalters@econ.berkeley.edu
}




\section{Introduction}

The feasibility of scaling up effective programs is a perennial problem in social policy. Successful demonstration projects often fail to reproduce their effects at scale. In the education sphere, for example, recent large-scale studies of early childhood programs, class size reductions, and the Success For All curriculum show effects that fall short of the impressive gains seen in smaller-scale evaluations of similar interventions (Heckman et al., 2010; Heckman, Pinto, and Savelyev, 2013; Puma, Bell, and Heid, 2012; Krueger, 1999; Jepsen and Rivkin, 2009; Borman et al., 2007; Quint et al., 2015). This suggests that in some cases the success of programs may be driven by unique inputs or population characteristics such as special teachers, school leaders, peer environments, or other factors that cannot be easily replicated (see Banerjee et al. (2017) on the challenges of scaling up demonstration programs, including general equilibrium and spillover effects and Davis et al. (2017) on the role of labor supply in scale-up).

The potential for sustained success at scale is of particular interest for "No Excuses" charter schools, a recent educational innovation that has demonstrated promise for low-income urban students. These schools share a set of practices that includes high expectations, strict discipline, increased time in school, frequent teacher feedback, high-intensity tutoring, and data-driven instruction. Evidence based on randomized admission lotteries shows that No Excuses charter schools generate test score gains large enough to close racial and socioeconomic achievement gaps in a short time, as well as improvements in longer-run outcomes like teen pregnancy and four-year college attendance (Abdulkadiroğlu et al., 2011, 2017; Angrist, Pathak, and Walters, 2013; Angrist et al., 2012, 2016; Dobbie and Fryer, 2011, 2013, 2015; Tuttle et al., 2013; Walters, 2018). Other recent studies demonstrate positive effects of No Excuses policies when implemented in traditional public schools or in low-performing schools converted to charter status (Fryer, 2014; Abdulkadiroğlu et al., 2016). No school district has adopted these policies on a wide scale, however, and No Excuses charters serve small shares of students in many of the cities where they operate. It therefore remains an open question whether the effects documented in previous research can be replicated at a larger scale. Replicability is of particular interest in the context of charter schools, which by design are intended to serve as laboratories of innovation and spread successful educational practices. ${ }^{1}$

\footnotetext{
${ }^{1}$ Massachusetts charters are required by law to disseminate their "best practices," see: http://www.doe.mass.edu/charter/bestpractices/ for details on the Massachusetts policy.
} 
We address this question using a recent policy change that expanded the charter school sector in Boston, Massachusetts, a city where most charter schools operate according to No Excuses principles. In 2010, Massachusetts passed a comprehensive education reform law that raised the state's cap on the fraction of funding dedicated to charter school tuition payments in low-performing districts. Charter operators that the state deemed "proven providers" with track records of success were permitted to expand existing campuses or open new schools in these districts. As a result, the number of charter schools in Boston increased from 16 to 32 between 2010 and 2014, with most of these new campuses linked to existing No Excuses charter schools. This expansion led to dramatic growth in charter market share in Boston: the fraction of sixth grade students attending charter schools increased from 15 to 31 percent between 2010 and 2015.

This increase in charter share is equivalent from going from the 100th ranked school district in terms of charter sector share to the 15th ranked school district (rankings from 2016-17, see David, Hesla, and Pendergrass 2017). ${ }^{2}$ Boston's charter expansion is therefore a large, policy relevant change in charter share. The closest studied analog is the expansion of the Knowledge is Power Program (KIPP) network of charter schools (Tuttle et al., 2015). Between 2010 and 2015, the KIPP network doubled the number of students served, from about 27,000 to 55,000 students. Observational estimates comparing KIPP students to matched comparisons showed that the network continued to boost student achievement over this period of expansion, but that these gains were smaller in the years of greater expansion. The KIPP setting is in contrast to our city-specific study, as the expansion of KIPP schools was diffuse, over many cities, and may not have had a great influence on the share of students in charters in a given locality.

Other localities are facing the potential for charter expansion similar to the policy change we study here. New York City reached its cap on the number of charter schools in the city in winter 2019 with 10 percent of students enrolled in charter schools. A policy change permitting more charters could result in an influx of charter schools, and would follow similar cap increases in 2007 and 2010 (New York State Department of Education, 2019). Massachusetts voters faced a decision about a referendum for another, similar charter school cap raise in 2016, which did not pass. Boston has again reached the cap on charter schools and thus the state may face future legislation about

\footnotetext{
${ }^{2}$ School district rankings are for all grade levels, and the charter share we focus on here is for middle schools. The leap for all grade levels is a move from approximately 208th to 63rd.
} 
changing the cap. Several states have also reached their overall cap on charter schools or have limited remaining growth, including Connecticut, Maine, Massachusetts (as previously discussed), and Rhode Island, setting these states up for policy decisions around further growth (Ziebarth and Palmer, 2018). The federal government also supports charter school replication, with several charter school networks receiving very large grants to replicate their models, including 2019 awards of over $\$ 100$ million to IDEA Public Schools and over $\$ 85$ million to KIPP. ${ }^{3}$

We use records from randomized charter school admission lotteries to study changes in the effectiveness of Boston's charter middle school sector during this period of rapid expansion. By comparing the outcomes of students who receive lottery offers to those that do not, we remove selection bias and therefore generate reliable estimates of the causal effects of charter school attendance. The lottery records studied here cover 14 of the 15 charter schools admitting students in fifth or sixth grade during the time period of our study. This is important in light of evidence that schools with more readily available lottery records tend to be more effective (Abdulkadiroğlu et al., 2011). Unlike previous studies that focus on subsets of oversubscribed charter schools, our estimates provide a representative picture of the effectiveness of the Boston charter middle school sector before and after expansion.

Consistent with past work, our estimates for cohorts applying before 2010 show large positive impacts of charter attendance on test scores. Specifically, a year of attendance at a Boston charter middle school boosted math achievement by between 0.18 and 0.32 standard deviations $(\sigma)$ and increased English achievement by about $0.1 \sigma$ during this period. Our results also indicate that policymakers selected more effective schools for expansion: proven providers produced larger effects than other charter schools before the reform.

Estimates for the post-reform period reveal that Boston's charter sector remained effective while doubling in size. Proven providers and other existing charters maintained their effectiveness after the reform, while expansion charters generate achievement gains comparable to those of their parent schools. Moreover, expansion charters produce these large impacts while enrolling students that appear more representative of the general Boston population than students at other charters. Together, the estimates for new and existing schools imply an increase in overall charter effectiveness

\footnotetext{
${ }^{3}$ For details on these awards, see: https://innovation.ed.gov/what-we-do/charter-schools/charter-schoolsprogram-grants-for-replications-and-expansion-of-high-quality-charter-schools/awards/.
} 
despite the substantial growth in charter market share after the 2010 reform.

We explore the roles of student composition, public school alternatives, and school practices in mediating the effectiveness of expansion charter schools. Though changes in demographic composition contributed modestly to the positive impacts of new charters, neither changes in the student body nor the quality of applicants' fallback traditional public schools explain the pattern of results. Instead, it appears that proven providers successfully transmitted hiring and pedagogical practices to new campuses. An analysis of teacher value-added indicates that charter schools reduce returns to experience and compress the distribution of teacher effectiveness while also employing a large share of new and inexperienced teachers. These findings are consistent with the possibility that Boston's charter schools use a highly standardized school model that limits teacher discretion, which may facilitate replicability in new contexts.

The next section provides background on charter schools in Boston and the charter expansion reform. Section 3 describes the data and Section 4 details the empirical framework used to analyze it. Section 5 presents lottery-based estimates of charter school effects before and after the reform. Section 6 explores the role of student composition and fallback schools, and Section 7 discusses charter management practices and teacher productivity. Section 8 offers concluding thoughts.

\section{Background}

\subsection{Charter Schools in Boston}

The first charter schools in Boston opened in 1994. Boston charters offer a different educational experience than traditional public schools operating in the Boston Public Schools (BPS) district. Table 1 compares inputs and practices of BPS schools and the 14 charter middle schools in our analysis sample (described in more detail later on). Columns (1) and (5) of Panel A show that charter students spend more days per year and hours per day in school than BPS students. Charter teachers tend to be younger and less experienced than BPS teachers; as a result, they are much less likely to be licensed or designated highly-qualified. ${ }^{4}$ Charter schools and BPS have similar student/teacher ratios, but charters spend somewhat less money per pupil ( $\$ 18,766$ vs. $\$ 17,041)$, a difference driven by lower salaries and retirement costs for their less-experienced teachers (Setren,

\footnotetext{
${ }^{4}$ In the time period of our study teachers were designated highly qualified if they possessed a Massachusetts teaching license and a bachelor's degree, and passed a state examination or held a degree in their subject area. The highly qualified label was discontinued with the passage of the federal Every Student Succeeds Act (ESSA) in 2015.
} 
2016).

Boston charter schools commonly subscribe to No Excuses pedagogy, an approach that utilizes strict discipline, extended instructional time, selective teacher hiring, frequent testing, high expectations, teacher feedback, data-driven instruction, and tutoring (Carter, 2000; Thernstrom and Thernstrom, 2003). Panel B of Table 1 reports the mean of an index of No Excuses policies, constructed as an equally-weighted average of features typically associated with the No Excuses model. ${ }^{5}$ On average, Boston charter schools implement 90 percent of these policies. Charters also commonly offer Saturday school and school break programming for homework help and tutoring. These practices differ markedly from practices at BPS schools and at non-urban charter schools in Massachusetts (Angrist, Pathak, and Walters, 2013).

Previous research has documented that Boston charters boost math and English standardized test scores (Abdulkadiroğlu et al., 2011; Cohodes et al., 2013; Walters, 2018). This finding is consistent with studies showing positive test score effects for urban No Excuses charters elsewhere (Dobbie and Fryer, 2011, 2013; Angrist et al., 2010, 2012; Chabrier, Cohodes, and Oreopoulos, 2016; Abdulkadiroğlu et al., 2017). Recent evidence shows that Boston charter high schools also increase longer-term outcomes, including SAT scores, Advanced Placement (AP) credit, and enrollment in four-year college (Angrist et al., 2016).

Funding for Massachusetts public school students follows their school enrollment. Specifically, charter schools receive tuition payments from their students' home districts equal to district perpupil expenditure. The state partially reimburses districts for charter school payments during a transition period, but these reimbursements have not been fully funded in recent years. Prior to 2010, Massachusetts law capped the overall number of charter schools at 120 and limited total charter school tuition to 9 percent of a district's spending. Charter expenditure in Boston reached this cap in fall 2009 (Boston Municipal Research Bureau, 2008). As a result, the charter cap limited the expansion of charter schools in Boston before 2010.

\footnotetext{
${ }^{5}$ The No Excuses index is an average of indicators equal to one if the following items are mentioned in a school's annual report: high expectations for academics, high expectations for behavior, strict behavior code, college preparatory curriculum, core values in school culture, selective teacher hiring or incentive pay, emphasis on math and reading, uniforms, hires Teach For America teachers, Teaching Fellows, or AmeriCorps members, affiliated with Teach For America alumni, data driven instruction, and regular teacher feedback.
} 


\subsection{Charter Expansion}

In January 2010, Governor Deval Patrick signed An Act Relative to the Achievement Gap into law. This reform relaxed Massachusetts' charter cap to allow the charter sector to double for districts in the lowest decile of performance according to a measure derived from test score levels and growth. The law also included provisions for school turnarounds and the creation of "innovation" schools (Massachusetts State Legislature, 2010).

For Boston and other affected districts, the 2010 reform increased the limit on charter spending from 9 percent to 18 percent of district funds between 2010 and 2017. "Proven providers" - existing schools or school models the Massachusetts Board of Elementary and Secondary Education deemed effective - could apply to open new schools or expand enrollment. The law also allowed school districts to create up to 14 "in-district" charter schools without prior approval from the local teachers' union or proven provider status. Concurrent with the increased supply of charter seats, the law required charters to increase recruitment and retention efforts for high need students and allowed charters to send advertising mailers to all students in the district. ${ }^{6}$

The state received 71 initial applications (some of which it solicited) for new charter schools or expansions from August 2010 to August 2012, and invited 60 percent of applicants to submit final round proposals. To determine whether a school model qualified for proven provider status, the Massachusetts Board of Elementary and Secondary Education compared existing schools using the model to other charters and traditional public schools. Criteria for this evaluation included enrollment of high-need students, attrition, grade retention, dropout, graduation, attendance, suspensions, and performance on state achievement tests (Massachusetts Department of Elementary and Secondary Education, 2015). The state granted proven provider status to four of seven Boston charter middle schools, as well as to the KIPP organization, which operated a charter school in Lynn, Massachusetts, but had not yet entered Boston. Together, the provisions of the 2010 reform led to the establishment of 27 new charter campuses between 2011 and 2013, as well as expansions of 17 existing charter schools, typically to new grade levels (Massachusetts Department of Elementary and Secondary Education, 2016).

\footnotetext{
${ }^{6}$ The state's definition of high need students includes those with special education or English language learner status, eligibility for subsidized lunch, or low scores on state achievement tests, as well as students deemed to be at risk of dropping out of school.
} 
Charter enrollment in Boston expanded rapidly after 2010. This can be seen in Figure 1, which plots shares of kindergarten, sixth, and ninth grade students attending charter schools. These statistics are calculated using the administrative enrollment data described below. Sixth grade charter enrollment doubled after the reform, expanding from 15 to 31 percent between 2010 and 2015. Charter enrollment also grew substantially in elementary and high school, though not as dramatically as in middle school. The share of Boston students in charter schools increased from 5 percent to 13 percent in kindergarten and from 9 percent to 15 percent in ninth grade over the same time period.

The characteristics and practices of Boston's new expansion charter schools are broadly similar to those of their proven provider parent schools. This is shown in columns (2) through (4) of Table 1, which describe proven providers, other charters operating before 2010, and new expansions. Like proven providers, expansion schools have longer school days and years than BPS schools, and rate highly on the index of No Excuses practices. Per-pupil expenditure is similar at proven provider and expansion schools, and lower at other charters. New campuses located an average of 3.1 miles from their parent campuses, often expanding into different Boston neighborhoods (see Figure 2).

Expansion charter schools are primarily staffed by young teachers with little teaching experience. Table 2 reports that 78 percent of teachers at proven providers in the year before expansion were less than 32 years old, while 87 percent of expansion charter teachers were below this threshold in the year after expansion. These and other teacher characteristics come from an administrative database of Massachusetts public school employees (see the Data Appendix). Columns (4) and (7) show that proven providers transferred some teachers from parent campuses to help staff their expansions: 12 percent of parent campus teachers moved to expansion campuses, accounting for 25 percent of the teaching workforce at these new schools. Transferred teachers were less experienced than teachers who remained at parent campuses (2.2 years vs. 3.3 years). Most of the remaining expansion teachers had not previously taught in a Massachusetts school (66 percent), though a few transferred from other schools (9 percent). As a result, the average teacher at an expansion charter had only 1.4 years of teaching experience, compared to 2.9 years for teachers at parent campuses and 11.5 years for BPS teachers. 


\section{Data}

\subsection{Data Sources and Sample Construction}

We study the effectiveness of Boston charter middle schools using records from randomized admission lotteries conducted between 2004 and 2013. Some charters serving middle school grades (fifth through eighth) accept students prior to fifth grade, mostly in kindergarten; we focus on schools with fifth or sixth grade entry because their lotteried students are old enough to take achievement tests within our data window. Our sample includes 14 of the 15 Boston charter schools with fifth or sixth grade entry, accounting for 94 percent of enrollment for schools in this category during the 2013-2014 school year. ${ }^{7}$

Lottery records typically list applicant names along with application grades, dates of birth, towns of residence and sibling statuses. Our analysis excludes sibling applicants, out-of-area applicants, and students who applied to non-entry grades (siblings are guaranteed admission, while out-ofarea applicants are typically ineligible). The lottery records also indicate which students received admission offers. We distinguish between immediate offers received on the day of the lottery and later offers received from the waitlist; in some lotteries all students eventually receive waitlist offers. All offers are coded as waitlist offers in a few lotteries where we cannot distinguish between immediate and waitlist offers. Further information on school coverage and lottery records appears in Appendix Tables A1 and A2. We use the "proven provider" label to refer to the four middle school charters in Boston that were granted permission to expand. The seven new campuses opened in the 2011-12 and 2012-13 school years are labeled "expansion charters," and the three remaining charter middle schools are "other charters."

We match the lottery records to state administrative data based on name, date of birth, town of residence and application cohort. The administrative data cover all students enrolled in Mas-

\footnotetext{
${ }^{7}$ Two charter middle schools that closed before 2010 are excluded from this calculation. The one missing school declined to provide lottery records.

${ }^{8}$ We categorize MATCH Middle School as a proven provider, as MATCH obtained that categorization from the state. MATCH's expansion campus opened at the elementary level, however. We categorize KIPP: Boston as an expansion campus, but this school does not have a direct parent campus in Boston as KIPP's only previous Massachusetts campus was in Lynn. We classify UP Academy as an expansion charter even though it opened under a different provision of the charter school law. To check whether our results are sensitive to these classification decisions, Appendix Table A4 reports an alternative version of our main results with these three schools categorized as "other charters." The findings here remain generally the same, with other charters demonstrating slightly larger effects and proven providers and expansion schools showing smaller gains than in our preferred specification.
} 
sachusetts public schools between 2002 and 2014. As shown in Appendix Table A3, we find matches for 95 percent of lottery applicants in this database. Administrative records include school enrollment, gender, race, special education status, English language learner status, subsidized lunch status, and test scores on Massachusetts Comprehensive Assessment System (MCAS) achievement tests. We standardize MCAS scores to have mean zero and standard deviation one for Boston students by subject, grade and year. In addition to information on charter lottery applicants, we use administrative data on other Boston students to describe changes in charter application and enrollment patterns after the 2010 reform. The Data Appendix provides more details regarding data processing and sample construction.

\subsection{Descriptive Statistics}

Charter application and enrollment patterns in our analysis sample mirror the large increases in charter market share displayed in Figure 1. As shown in Table 3, 15 percent of eligible Boston students applied to charter schools with fifth or sixth grade entry before the 2010 reform, 12 percent received offers from these schools, and 10 percent enrolled. This implies roughly 1.5 applicants for each available charter seat. The application rate increased to 35 percent in 2013, and attendance reached 17 percent..$^{9}$ The increase in applications therefore outpaced enrollment growth, boosting the number of applicants per seat to 2. This increase in demand was particularly pronounced at other charter schools (neither proven providers nor expansions), which saw their applications per seat rise from 1.9 to $4 .{ }^{10}$ After the expansion, half of charter school sixth grade students attended new expansion campuses.

Table 4 describes the characteristics of Boston middle school students in BPS, charter schools, and our randomized lottery applicant sample. Charter applicants and enrollees are consistently more likely to be black than BPS students. Both before and after 2010, students attending proven providers were less disadvantaged than other Boston students as measured by special education status, limited English proficiency, and fourth grade test scores. Past achievement and other char-

\footnotetext{
${ }^{9}$ These attendance percentages are lower than the percentages in Figure 1, since they exclude charter schools that enroll students at earlier entry grade levels.

${ }^{10}$ The number of applicants per seat is larger for each individual charter type than for the sector as a whole because some students apply to more than one school.
} 
acteristics of students enrolled at proven providers and randomized applicants were similar before the reform, but diverged somewhat afterward. This is due to the fact that one proven provider campus transitioned to a K - 8 structure in 2010-11 by grandfathering students from its elementary school instead of filling its entire fifth grade via random lottery.

As shown in columns (11) and (12) of Table 4, the characteristics of students enrolled at expansion charters differ markedly from those of other charter students. Special education and limited English proficiency rates are similar at expansion charters and in the BPS population. Expansion charter students also score below the BPS average on 4th grade math and English tests, and are more likely than BPS students to be eligible for subsidized lunches. These facts indicate that expansion charters attract a more disadvantaged, lower-achieving population than their proven provider parent schools. This pattern may reflect the changes in recruitment practices resulting from the 2010 Achievement Gap Act, which mandated that charter schools take steps to enroll higher-need students and allowed charters to advertise directly to all students in the district by mail.

\section{Empirical Framework}

We use charter lottery offers as instruments for charter school attendance in a causal model with multiple endogenous variables, each representing enrollment in a type of charter school. The structural equation links charter attendance with outcomes as follows:

$$
Y_{i g}=\alpha_{g}+\sum_{k=1}^{K} \beta_{k} C_{i g}^{k}+\sum_{j=1}^{J} \delta_{j} R_{i j}+X_{i}^{\prime} \gamma+\epsilon_{i g}
$$

where $Y_{i g}$ is a test score for charter applicant $i$ in grade $g$ and $C_{i g}^{k}$ measures years of enrollment in charter school type $k$ through grade $g$. Charter types include parent campuses, expansion campuses, and other charters; we also distinguish between enrollment before and after the charter expansion law. The parameters of interest, $\beta_{k}$, represent causal effects of an additional year of attendance at each charter type relative to traditional public schools. The key control variables in equation (1) are a set of indicators, $R_{i j}$, for all combinations of charter lottery applications present in the data. Lottery offers are randomly assigned within these "risk sets." A vector of baseline demographic characteristics, $X_{i}$, is also included to increase precision. These characteristics, which are measured in 
the year prior to a student's lottery application, include gender, race, a female-minority interaction, subsidized lunch status, English language learner status, and special education status.

The first stage equations for each charter enrollment type are given by:

$$
C_{i g}^{k}=\mu_{g}^{k}+\sum_{\ell=1}^{K}\left(\pi_{\ell 1}^{k} Z_{i 1}^{\ell}+\pi_{\ell 2}^{k} Z_{i 2}^{\ell}\right)+\sum_{j=1}^{J} \lambda_{j}^{k} R_{i j}+X_{i}^{\prime} \theta^{k}+\eta_{i g}^{k} ; k=1 \ldots K .
$$

Here $Z_{i 1}^{k}$ denotes a dummy variable equal to one if applicant $i$ received an immediate offer to attend charter type $k$ on the day of a lottery, and $Z_{i 2}^{k}$ equals one if the applicant later received an offer from the waitlist. Like equation (1), the first stage also controls for lottery risk set indicators and baseline student characteristics. Two-stage least squares (2SLS) estimates are obtained by ordinary least squares (OLS) estimation of equation (1) after substituting predicted values from (2) for the charter attendance variables. The estimation sample stacks all post-lottery test scores in grades five through eight for randomized charter applicants, and standard errors are clustered by student to account for correlation in outcomes across grades.

Our empirical strategy is motivated by the fact that charter lottery offers are randomly assigned within lottery risk sets and are therefore independent of ability, family background, and all other predetermined student attributes. Appendix Table A5 presents a check on this by comparing baseline characteristics for offered and non-offered applicants within lottery risk sets. These comparisons show that lottery winners and losers are similar for all charter school types and time periods, indicating that random assignment was successful. ${ }^{11}$

\section{$5 \quad$ Lottery Estimates}

We begin by reporting a pooled set of 2SLS impact estimates for all Boston charter middle schools across our full sample period. These estimates, which appear in Table 5, come from a version of equations (1) and (2) that uses a single instrument (any charter offer) to instrument for a single endogenous variable (total years in charter). The first stage estimate in column (1) shows that a charter school offer increases charter attendance by an average of one year. Column (2)

\footnotetext{
${ }^{11}$ Even with random assignment, selective attrition may lead to bias in comparisons of lottery winners and losers. Appendix Tables A3 and A6 show that the attrition rate from our sample is low: we match 95 percent of applicants to the administrative data, and find roughly 85 percent of post-lottery test scores that should be observed in our sample window for matched students. The match rate is 4 percent higher for students offered charter seats, and we are 3 percent more likely to find scores for students with lottery offers at non-proven-provider charters before 2010. This modest differential attrition seems unlikely to meaningfully affect the results reported below.
} 
reports reduced form differences in test scores between lottery winners and losers. The results here show that lottery winners outscore losers by $0.22 \sigma$ in math and $0.12 \sigma$ in ELA. Because the first stage is roughly one, the 2SLS estimates in column (3) are similar to the reduced form, implying that a year of charter attendance boosts math and ELA scores by $0.22 \sigma$ and $0.12 \sigma$ on average. These results, which represent the most precise and representative estimates of the effectiveness of Boston's charter sector to date, are similar to the effects reported by Abdulkadiroğlu et al. (2011) in a subsample of the schools and cohorts studied here.

Proven provider charter schools generated larger achievement gains than other charter schools in Boston prior to the 2010 expansion. This can be seen in Table 6, which reports second-stage estimates of equation (1). ${ }^{12}$ Columns (2) and (3) demonstrate that a year of charter attendance at a proven provider increased math and English scores by $0.32 \sigma$ and $0.12 \sigma$ prior to the reform, estimates that are highly statistically significant. Corresponding math and English effects for other Boston charters equal $0.18 \sigma$ and $0.08 \sigma$. The difference in effects for proven providers and other charters is statistically significant in math $(p=0.00)$, though not in English. This finding indicates that policymakers selected more effective charter schools to be eligible for expansion.

Proven providers and other charters maintained their effectiveness after the charter expansion reform. As shown in columns (5) and (7) of Table 6, proven providers boost math and English scores by $0.37 \sigma$ and $0.19 \sigma$ per year of attendance after 2010, while other charters increase scores by $0.19 \sigma$ and $0.13 \sigma$ in this period. These estimates are slightly larger than estimates for earlier cohorts, though the differences between pre- and post-reform effects are not statistically significant for either group. As in the pre-reform period, the difference in effects between proven providers and other charters is significant in math $(p=0.03)$. These results indicate that expanding to operate new campuses did not dilute the effectiveness of proven provider charters at their original campuses.

Proven providers also successfully replicated their impacts at expansion schools. Column (6) of Table 6 demonstrates that a year of attendance at an expansion charter school increases math and English test scores by $0.32 \sigma$ and $0.23 \sigma$. These estimates are comparable to estimates for parent campuses, and the hypothesis that expansion and proven provider effects are equal cannot

\footnotetext{
${ }^{12}$ Appendix Table A7 reports first stage estimates separately by charter type. The first stage coefficients are generally smaller in the post-expansion period for all charter types. This reflects the fact that less time has elapsed in our data for cohorts applying after 2010, resulting in fewer years of potential charter enrollment between lottery and test dates. Reduced form estimates are reported in Appendix Table A8 and OLS estimates of charter school effects that control for prior test scores and baseline characteristics are in Appendix Table A9.
} 
be rejected at conventional levels ( $p=0.63$ and 0.62 in math and English). Estimated effects for expansion charters are larger than corresponding estimates for other charters during the same time period, though these differences are only marginally statistically significant for math and not statistically significant for English. Combined with the consistent effects for proven providers and other charters over time, these results indicate that Boston's charter middle school sector slightly increased its average effectiveness despite the growth in charter market share over this period.

\section{Exploring Effect Heterogeneity}

The impacts of expansion charters are particularly striking in view of the changes in selection documented in Table 4: new charter campuses continue to generate large effects despite serving more typical students. This suggests that positive charter effects are not an artifact of a positivelyselected peer environment. This finding is also consistent with results reported by Walters (2018), which suggest that charter effects are larger for the average Boston student than for the average charter applicant, as well as estimates in Abdulkadiroğlu et al. (2016), which indicate that charter effects are larger for students passively enrolled in charters through school conversion than for students who voluntarily apply through lotteries. We further investigate the impact of changes in the charter population on the effects of charter expansion by studying effect heterogeneity across subgroups and changes in the quality of the fallback traditional public schools available to charter applicants.

\subsection{Student Characteristics}

The 2010 charter expansion law encourages charter schools to recruit and retain students with higher needs, as measured by criteria including English proficiency, special education status and past achievement. Appendix Table A10 summarizes effect heterogeneity as a function of these characteristics.

The estimates show consistent positive impacts across most subgroups, charter school types, time periods and subjects. Effects are similar for English language learners and students without this designation, though estimates for the former group are often imprecise due to small sample sizes. All estimates are positive for students with and without special education status; effects for special education students appear to be somewhat smaller at proven providers and larger at 
expansion charters, but these differences may be a chance finding due to the many splits examined. As in previous studies (e.g., Walters, 2018), we find that effects tend to be larger for students with lower previous test scores. The large estimated effects for high-need subgroups at expansion charters are noteworthy: expansion schools continue to generate substantial gains for these groups despite serving larger shares of such students than other Boston charters.

We analyze the role of this heterogeneity in the effectiveness of charter expansion via a OaxacaBlinder (1973)-style decomposition, which splits charter school treatment effects into components explained and unexplained by student characteristics. This decomposition is based on 2SLS models of the form:

$$
Y_{i g}=\alpha_{g}+\sum_{k=1}^{K}\left(\beta_{k}^{0}+X_{i}^{\prime} \beta^{x}\right) C_{i g}^{k}+\sum_{j=1}^{J} \delta_{j} R_{i j}+X_{i}^{\prime} \gamma+\epsilon_{i g}
$$

Equation (3) allows a separate main effect for attendance at each charter type $\left(\beta_{k}^{0}\right)$ as well as an interaction with student characteristics common across charter types $\left(\beta^{x}\right)$. Charter exposure $C_{i g}^{k}$ and its interactions with $X_{i}$ are treated as endogenous. The immediate and waitlist offer variables for each charter type $Z_{i 1}^{k}, Z_{i 2}^{k}$, and their interactions with $X_{i}$ are the excluded instruments.

Let $\bar{X}_{k}$ denote the average characteristics of students attending charter $k$, and let $\mu^{x} \equiv E\left[X_{i}\right]$ denote the mean of $X_{i}$ for the Boston population. The effect of charter type $k$ for students enrolled at $k$ (the effect of treatment on the treated, $T O T_{k}$ ) can be represented:

$$
\begin{gathered}
\operatorname{TOT}_{k}=\beta_{k}^{0}+\bar{X}_{k}^{\prime} \beta^{x} \\
=\underbrace{\left(\beta_{k}^{0}+\mu^{x \prime} \beta^{x}\right)}_{A T E_{k}}+\underbrace{\left(\bar{X}_{k}-\mu^{x}\right)^{\prime} \beta^{x}}_{\text {Match }_{k}} .
\end{gathered}
$$

This expression decomposes the TOT for charter type $k$ into an average treatment effect for the Boston population, $A T E_{k}$, and a deviation from the average treatment effect due to the characteristics of type $k$ 's students, $M a t c h k$. We quantify the contribution of student characteristics to charter school effectiveness by studying estimates of $A T E_{k}$ and $M a t c h_{k}$ for each school type and time period.

Table 7 reports estimates of the components of the decomposition in equation (4), using gender, race, ethnicity, English language learner status, subsidized lunch, special education, and baseline test scores as interaction variables. Two-stage least squares estimates appear in panel A, and panel 
B displays corresponding OLS estimates for comparison. As with the treatment effect estimates in Table A9, the OLS decomposition results tend to be qualitatively similar and more precise than the 2SLS results. Estimated match components are close to zero for proven providers in both time periods, while match components for other charters are negative in both periods. This indicates that the demographic composition of other charters reduces their effectiveness, a result that is consistent with Walters' (2018) finding that disadvantaged students were less likely to apply to Boston charter schools despite experiencing larger achievement benefits in data prior to the reform.

In contrast, column (4) reveals positive match effects for expansion charter schools. This pattern is due to the fact that expansion charters enroll a lower-achieving set of students compared to other charters (see Table 4). Since achievement gains are larger for this group, the match effect reinforces the effectiveness of expansion charters. The magnitudes of these match effects are relatively small, however, accounting for roughly 4 percent and 8 percent of the TOT in math and ELA. Evidently, changes in student characteristics increased the effectiveness of new charter campuses but were not the primary driver of the effectiveness of expansion schools.

\subsection{Fallback Schools}

One potential explanation for the success of Boston charter school expansion, where other efforts at program replication have been less successful, is that students in expansion campuses face particularly poor alternatives if they do not attend a charter school. Chabrier, Cohodes, and Oreopolous (2016) find that poor fallback school options are one of the strongest predictors of charter school effectiveness. It also is possible that charter schools influence the counterfactual by diverting resources from district schools, as is the case in Arsen and Ni (2012); Bifulco and Reback (2014); Cook (2018); Ladd and Singleton (2018). However Ridley and Terrier (2018) find small gains in district school finances (and test scores) in Massachusetts using the same charter expansion law. ${ }^{13}$ Expansion campuses in Boston may have located in areas where students' counterfactual schools were lower-performing. To see if low-quality fallback schools explain the success of expansion campuses, we compare fallback school conditions across charter school types, both before and after charter

\footnotetext{
${ }^{13}$ Other studies of competitive effects of charter schools on nearby district schools' test scores generally find no or small positive impacts (Booker et al., 2008; Cordes, 2018; Jinnai, 2014; Davis, 2013; Sass, 2006; Shin, Fuller, and Dauter, 2017; Winters, 2012; Zimmer et al., 2009; Zimmer and Buddin, 2009). One exception is Imberman (2011) which found a mix of neutral and negative effects. For reviews of this literature, see: Betts (2009); Gill and Booker (2008); Gill (2016); Epple, Romano, and Zimmer (2016).
} 
school expansion.

Table 8 shows average school-level value-added estimates for traditional public schools attended by students that enroll in district schools as a result of losing a charter lottery (untreated compliers). ${ }^{14}$ Value-added estimates are OLS coefficients from regressions of test scores on school indicators, with controls for lagged test scores and demographics. Specification tests reported by Angrist et al. (2017) indicate that estimates from models of this type provide a reasonable proxy for school effectiveness. In both math and ELA, estimated value-added of the traditional public school fallback alternatives attended by charter applicants does not differ by charter school type, and these fallback schools appear to be of roughly average quality among schools in BPS. Students' fallback options therefore do not seem to be an important component of variation in effects across charter types or time periods.

\section{School Practices}

Our results so far show that changes in student characteristics and the quality of applicants' fallback schools do not explain the effectiveness of expansion charters. This suggests that successful replication of the Boston charter model may be driven by attributes of the expansion schools themselves. We explore this hypothesis by providing a more detailed account of organizational practices at parent and expansion charter schools in Boston. This portion of our analysis includes a qualitative overview of the mechanics of charter expansion based on interviews with school leaders ( $\mathrm{S}$. Dunn, J. Clark, W. Austin, A. Hall, and D. Lehman, personal communication, May 2017), as well as a quantitative assessment of teacher value-added that gives an indication of how heterogeneity in teacher quality is managed in traditional public and charter schools.

\subsection{Standardized School Models and Leadership}

Proven provider charter schools sought to maintain fidelity of their school models during expansion by emphasizing adherence to the same educational practices at new campuses. Table 1 shows a comparison of practices at parent and expansion charters based on information drawn from charter

\footnotetext{
${ }^{14}$ We estimate untreated complier outcomes using methods from Abadie (2002).
} 
school annual reports. ${ }^{15}$ Expansion schools typically have the same amount of instructional time as their parent campuses, including identical length of the school day, time devoted to math and reading instruction, and days in the school year. ${ }^{16}$ Expansion schools similarly implemented their parent campuses' No Excuses practices, tutoring, homework help, and Saturday school programs.

Expanding charter networks also tried to maintain similar pedagogical practices at old and new campuses. Teachers co-planned curricula and teachers judged to be effective were encouraged to share their lesson plans across the network. This model of shared teaching resources was aimed at supporting new, inexperienced teachers, who comprised two thirds of the new schools' staff. Survey evidence from Boston charters indicates that such collaboration is common within the sector, with 59 percent of new teachers reporting co-planning the curriculum with their peers (Gabbianelli, McGovern, and Wu, 2014). Recent evidence from other contexts shows that such collaboration can increase student achievement (Jackson and Bruegmann, 2009; Ronfeldt et al., 2015; Papay et al., 2016; Sun, Loeb, and Grissom, 2017) and that access to high quality lesson plans also boosts student achievement (Jackson and Makarin 2018). Fryer (2014) found that charter practices, similar to those used in Boston charters, can be successfully transfered to traditional public schools.

High teacher turnover rates are the norm at Boston charter schools. This is shown in Table 9, which summarizes teacher mobility patterns at charter and traditional public schools. As a result, some practices aimed at quickly training new teachers were in place prior to the 2010 reform. This may have aided schools' efforts to bring inexperienced teachers at new campuses up to speed on key practices. Two charter networks run their own teacher training programs and hired some of the graduates as full-time teachers. Charter networks also centralized teacher recruitment and professional development, potentially saving on search costs and resulting in similar types of teachers hired at new and old schools. Each network reported conducting some share of professional development at the network level.

Growing charter networks had stable leadership throughout the scaling up process. Principals in the new and original campuses did not change throughout the expansion period in this study. ${ }^{17}$

\footnotetext{
${ }^{15}$ The Massachusetts Department of Elementary and Secondary Education provided the 2012-13 annual reports for each of the Boston charter middle schools at our request. The state requires charter schools to submit annual reports and uses the reports when considering schools' charter renewal applications.

${ }^{16}$ Edward Brooke's replication campus in East Boston is an exception, with six more days in its school year than its parent campus.

${ }^{17}$ We verified this in Education Personnel Information Management Systems (EPIMS), the educator database available from the Department of Elementary and Secondary Education, which contains yearly staff level data for all
} 
Furthermore, principals were trained internally: all of the principals at expansion campuses were former teachers from the original campus. School leaders who oversaw their network's expansion stressed the value of selecting principals from within the network because they are familiar with core school practices. Columns (3) and (6) of Table 9 show that roughly 4 percent of charter school teachers were promoted to a leadership position from 2011 to 2014, compared to less than 1 percent of BPS teachers.

\subsection{Evidence on Teacher Productivity}

The qualitative evidence above suggests that Boston charter schools limit teacher discretion by emphasizing a standard set of pedagogical practices, which may facilitate efforts to implement similar school models at new campuses. We assess this quantitatively by studying variation in teacher value-added at charter and district schools. Teacher value-added estimates come from the following model for achievement of student $i$ in grade $g$ in calendar year $t$ :

$$
Y_{i g t}=\alpha_{g}+\lambda_{t}+X_{i g t}^{\prime} \gamma+\beta_{s(i, g)}+\theta_{j(i, g) t}+\delta_{c(i, g, t)}+\xi_{i}+\epsilon_{i g t}
$$

The control vector $X_{\text {igt }}$ includes student demographic characteristics and lagged test scores, as well as classroom-level averages of these variables. We also include grade $\left(\alpha_{g}\right)$ and calendar year $\left(\lambda_{t}\right)$ fixed effects. The function $s(i, g)$ labels the school that student $i$ attends for grade $g, j(i, g)$ describes the identity of her grade $g$ teacher, and $c(i, g, t)$ denotes a specific classroom. Because classroomlevel averages of the observables are included as controls, (5) describes a "correlated random effects" model in which the mean of the teacher effect distribution may depend on the characteristics of students in the classroom (Mundlak, 1978; Chamberlain, 1982). In other words, we are not imposing independence of teacher quality from student observables.

We also allow school and teacher effects to depend on observed school and teacher characteristics. The mean of the distribution ofschool effects $\beta_{s}$ differs for charter and traditional public schools. The teacher effects (which measure variation in teacher effectiveness within school) are in turn written:

$$
\theta_{j t}=\theta_{j}^{0}+W_{j t}^{\prime} \theta^{w}
$$

employees in Massachusetts public schools. 
where $W_{j t}$ includes teacher $j$ 's experience as of year $t$ in one of three experience groups (novice, 1 to 4 years of experience, and greater than five years of experience) as well as interactions of charter status with experience. Given the small number of charter teachers in the sample, we do not separate teachers at proven providers, expansions, and other charters for the purposes of the valueadded model, nor do we estimate experience premia for each year. ${ }^{18}$ We model the school effects $\beta_{s}$, within-school teacher effects $\theta_{j}^{0}$, and classroom effects $\delta_{c}$ as normally distributed conditional on $X_{i g t}$, with variances that differ in charter and traditional public schools. The student random effect $\xi_{i}$ and idiosyncratic error $\epsilon_{i g t}$ are also modeled as normally distributed. Random effects specifications of this sort are common in the literature on teacher value-added, and previous studies have argued that such models generate estimates of teacher effectiveness that exhibit little selection bias (Kane, Rockoff, and Staiger, 2008; Chetty, Friedman, and Rockoff, 2014). ${ }^{19}$

As can be seen in Table 10, maximum likelihood estimation of model (5) produces two notable findings. First, returns to teacher experience seem to beless pronounced in charter schools than in BPS. Comparing teachers with 1 to 4 years of experience and teachers with 5 or more years of experience to novices shows that more experienced teachers generally outperform new teachers. However, the experience premium is larger in BPS (though the differences are not statistically significant), with teachers with 1 to 4 years of experience outperforming novice teachers in BPS by about $0.09 \sigma$ in both math and English. The corresponding experience premia for teachers in charter schools equal $0.06 \sigma$ and $0.04 \sigma$. For teachers with more than 5 years of experience, BPS teachers maintain their edge relative to novices, but any premium for charter school teachers is small and not statistically significant. In short, either through selection of teachers or through training, charter schools dampen one of the most persistent findings in the literature on teacher effectiveness (Harris 2011; Papay and Kraft 2015; Clotfelter, Ladd, and Vigdor 2007; Rockoff 2004) - that teachers make significant gains in their first few years of teaching. Evidently, teachers at charter schools deliver effective education despite the high proportion of novice teachers and substantial teacher turnover. We caution, however, that while our estimates of the difference in experience profiles between the

\footnotetext{
${ }^{18}$ Data for the value-added model are from 2011-2015, the years in which it is possible to link students, teachers, and classrooms in the state data.

${ }^{19}$ Our findings are robust to variants of this model. We estimated versions where we used teacher random effects, teacher and school random effects, teacher fixed effects, and school and teacher fixed effects. We also ran versions that added student random effects, phased in controls, restricted to the sample to exclude students who attended both Charter and BPS during middle school, and used finer years of experience indicators to similar findings.
} 
two sectors are quantitatively large, we cannot reject the hypothesis that these parameters are equal due to a lack of statistical precision.

The second notable finding from the value-added analysis is revealed by comparing variation in school, teacher, and class effects across the charter and traditional sectors. Both charter and district schools have similar variation in school-level effectiveness. At the teacher and classroom levels, we find less variation in effectiveness in the charter sector. In math, the standard deviation of the teacher random effect $\theta_{j}^{0}$ is $0.12 \sigma$ compared to $0.19 \sigma$ in BPS, while the standard deviation of the class effect $\delta_{c}$ is $0.08 \sigma$ compared to $0.15 \sigma{ }^{20}$ This suggests that the charter sector reduces variation in teacher effectiveness within schools, which may be due to charters' centralized management of teachers and standardized instructional practices. ${ }^{21}$ Additionally, the charter hiring practices could select teachers with less variation in their practices, though this would also be part of a management strategy. The reduction in variation at the classroom level (which is typically attributed to random events like construction noise on test day) suggests some of this variation is systematic and can be reduced through standardized practices as well. Both conclusions from the value-added analysis are consistent with the hypothesis that highly standardized management practices may contribute to the successful replication of charter school effects.

\section{Conclusion}

The replication and expansion of successful schools is one strategy to address persistent achievement gaps in the United States. The efficacy of this strategy requires schools selected for expansion to maintain their success at new locations and with new student populations. Previous research has shown that urban No Excuses charter schools boost test scores markedly for small groups of applicants, suggesting the potential for transformational effects on urban achievement if these gains can be maintained at larger scales. We examine a recent policy change in Massachusetts that doubled Boston's charter sector over a short time period, allowing us to evaluate changes in the

\footnotetext{
${ }^{20}$ The results found here - that charter value-added standard deviations are around 0.11 and district about 0.18 indicate that charter schools in Boston are toward the minimum known range of teacher, value-added whereas Boston district schools are in the middle of the distribution. Hanushek and Rivkin (2010) review the dispersion of teacher value-added in 10 localities, and find that the standard deviation of teacher effects ranges between 0.11 and $0.36 \sigma$ in math and 0.10 and $0.26 \sigma$ in reading.

${ }^{21}$ Taylor (2018) and Jackson and Makarin (2018) also show a compression of the teacher value-added distribution when there are standardized instructional practices. In Taylor (2018), standardization comes from the use of computer-aided instruction; in Jackson and Makarin (2018) from access to high-quality instructional materials.
} 
effects of No Excuses charters as these schools expanded to serve a larger share of the population.

Our results demonstrate that Boston's No Excuses charters reproduced their effectiveness at new campuses. Lottery-based estimates show that schools selected for expansion produced larger gains than other charters in the pre-reform period, indicating that Massachusetts' accountability regime successfully identified more successful schools. New expansion campuses generate test score gains similar to those of their parent campuses despite a doubling of charter market share in middle school.

The demographics of students served by expansion charters are similar to those of the Boston population as a whole, suggesting that charter effectiveness is not driven by unique peer environments. We find that changing student populations and the quality of fallback traditional public schools play only a small role in the effectiveness of charter expansion, however. Both a qualitative analysis of organizational practices during expansion and a quantitative analysis of variation in teacher value-added indicate that charter schools use a highly standardized model that limits variation in practices across schools and classrooms. This standardized approach may facilitate the portability of charter effectiveness to new campuses. More broadly, the role of these and other organizational practices in explaining successful replication of social programs is an important area for future work.

This paper also brings evidence to bear on the best agent for replicating social programs. When a program is successful, policymakers face the decision of whether to have the original implementer continue to provide the program, or whether governments or other agencies should take over the program at a larger scale. This paper shows that, in the charter school context, replicating existing charters may be a better option than allowing new providers to enter the sector. This is consistent with the findings of Bold et al. (2018), which shows that the successful Kenyan contract teacher program evaluated in Duflo et al. 2011; 2015 was replicated with provision by the original provider, but not with the government (despite an identical contract). The "proven provider" design of the Massachusetts 2010 charter law is unique among the states with charter school laws, and it remains to be seen if other states or charter authorizers adopt such policies. However, the share of charter schools managed by charter school management organizations (independent, non-profit organizations that manage two or more charter schools) has grown from 16 percent in 2009 (Furgeson et al., 2011) to 23 percent in 2017 (David, 2018), indicating that the market may institute a replication 
strategy even if authorizors do not. 


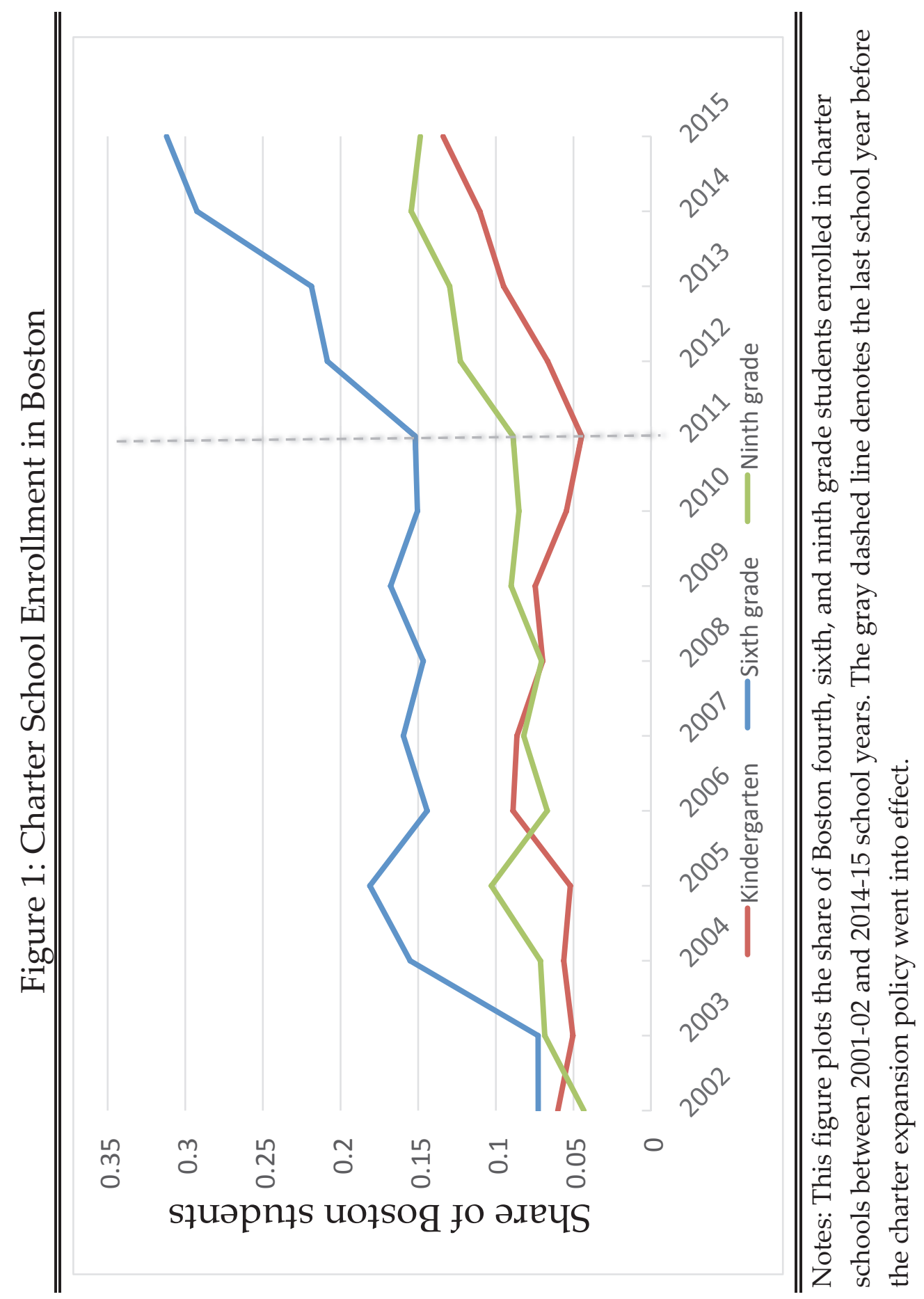




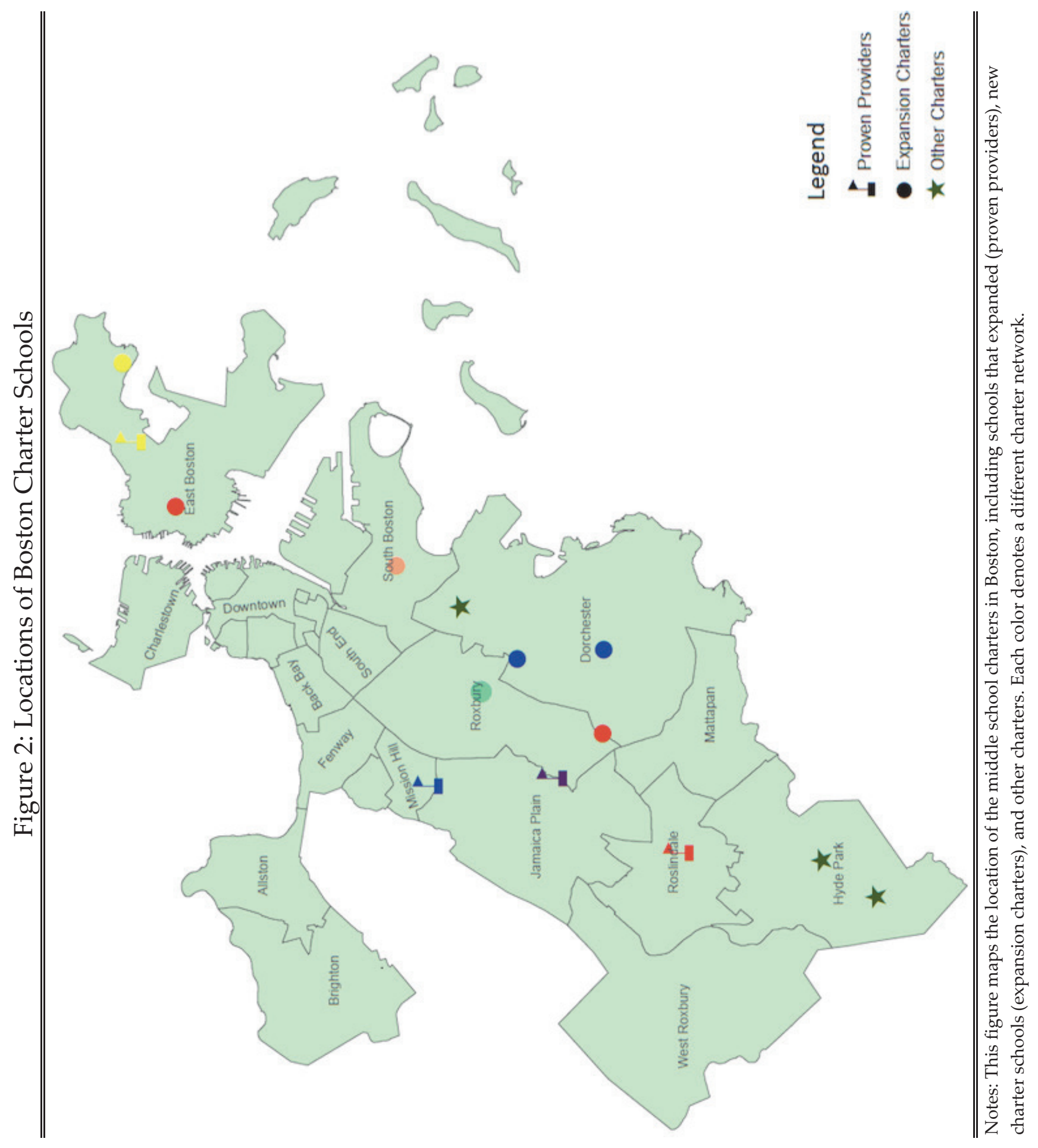




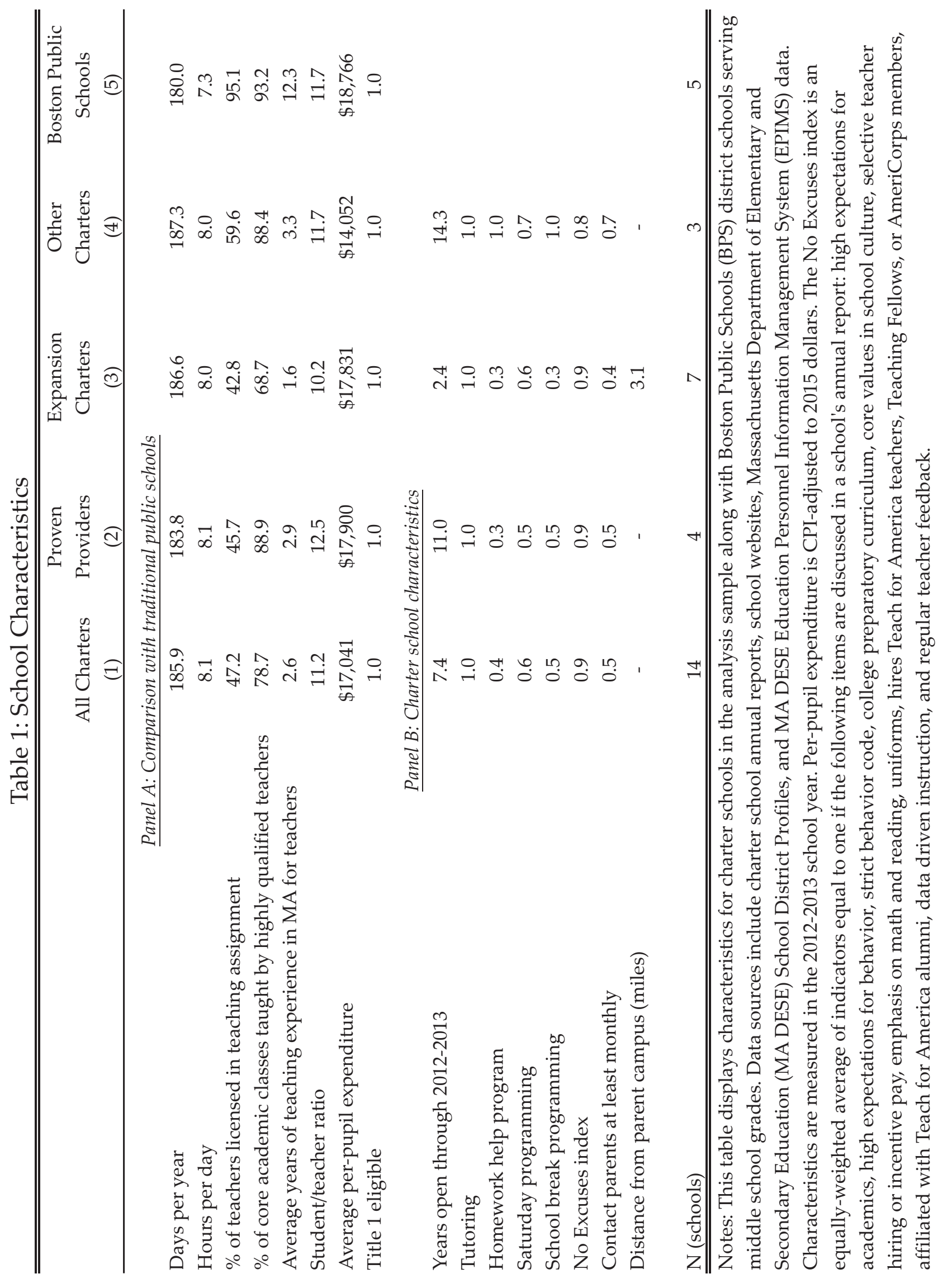




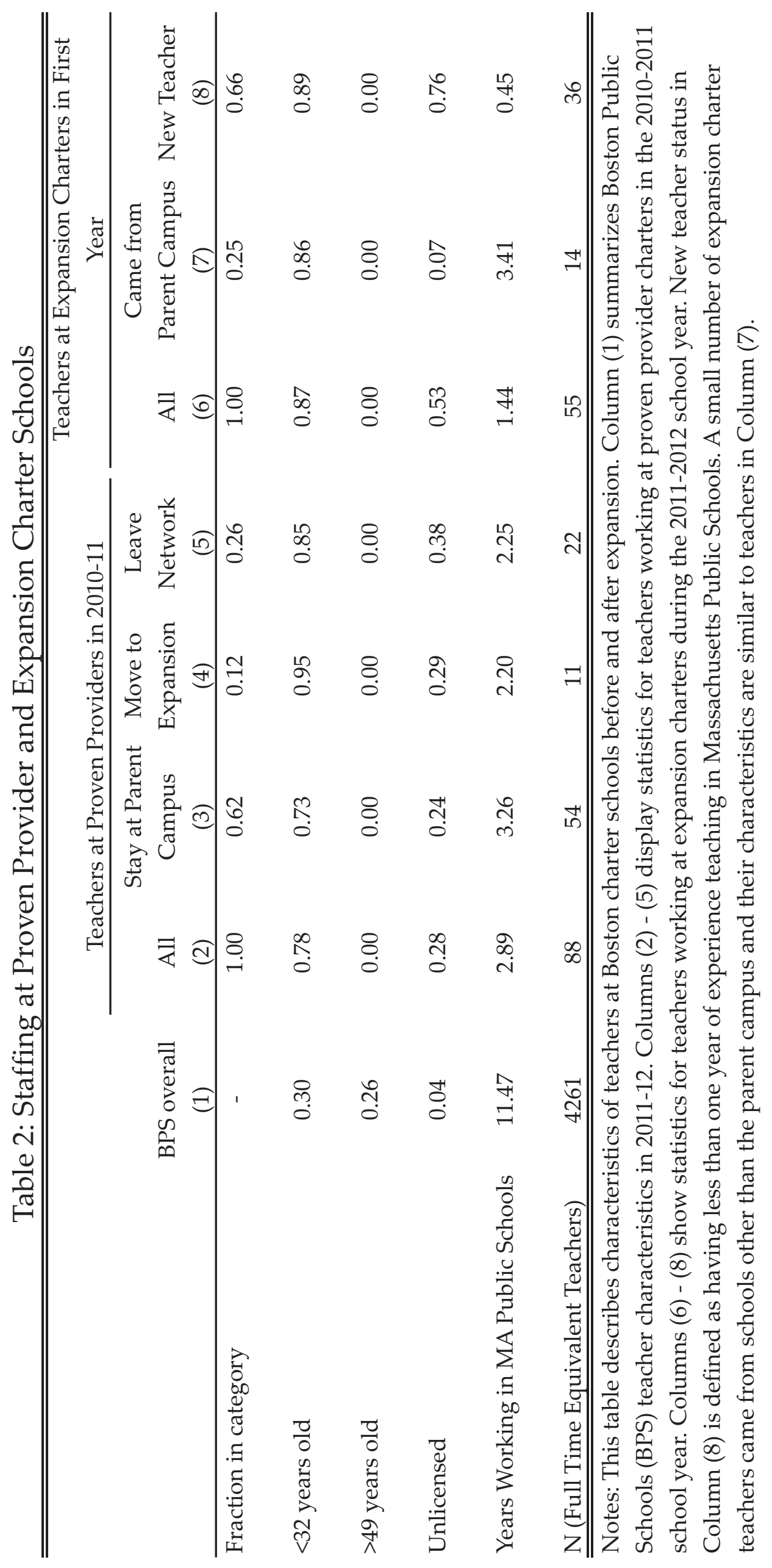




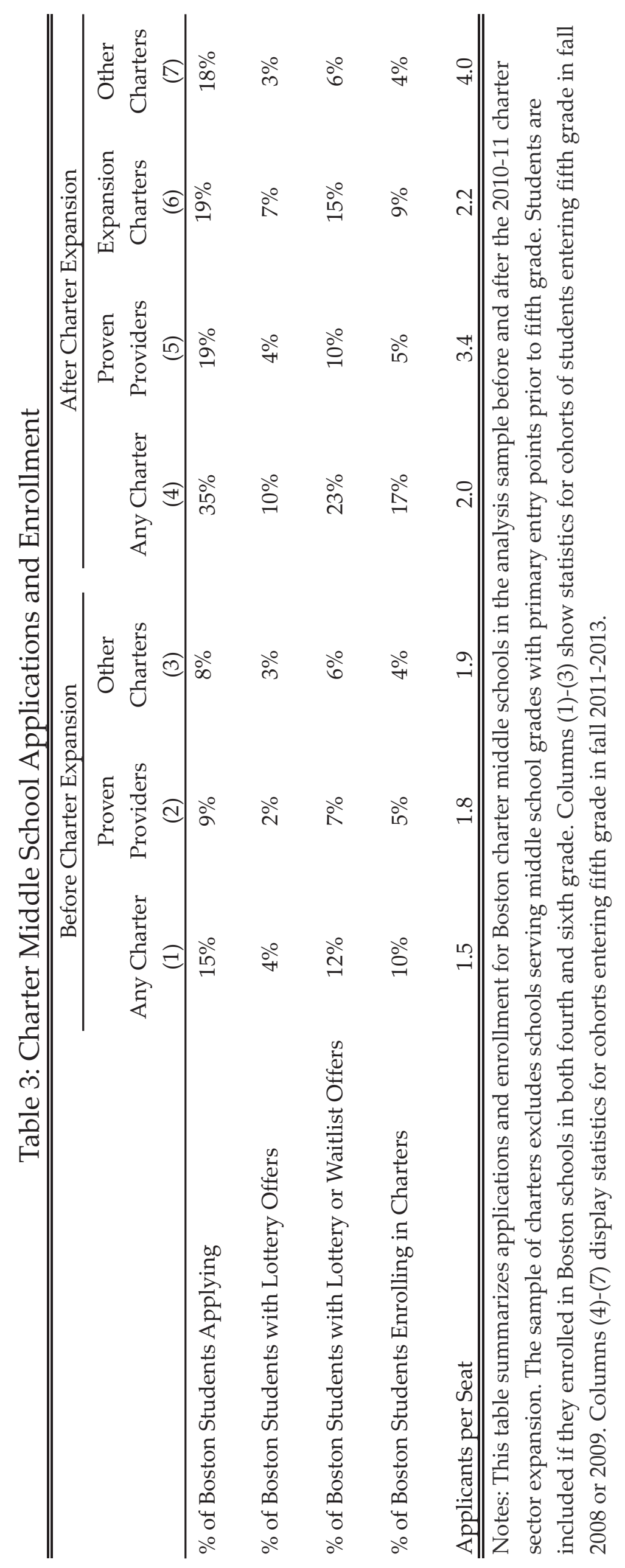




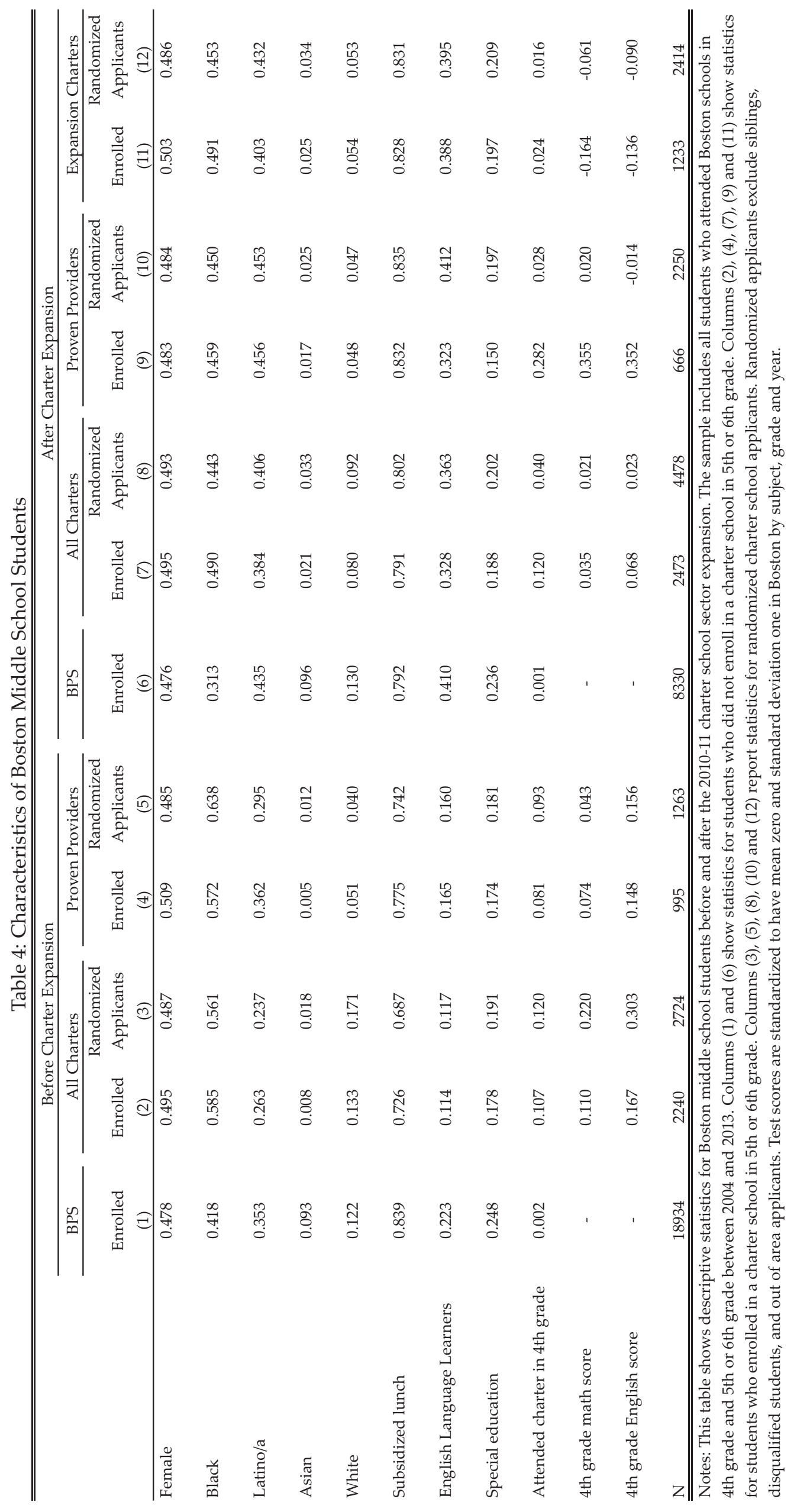




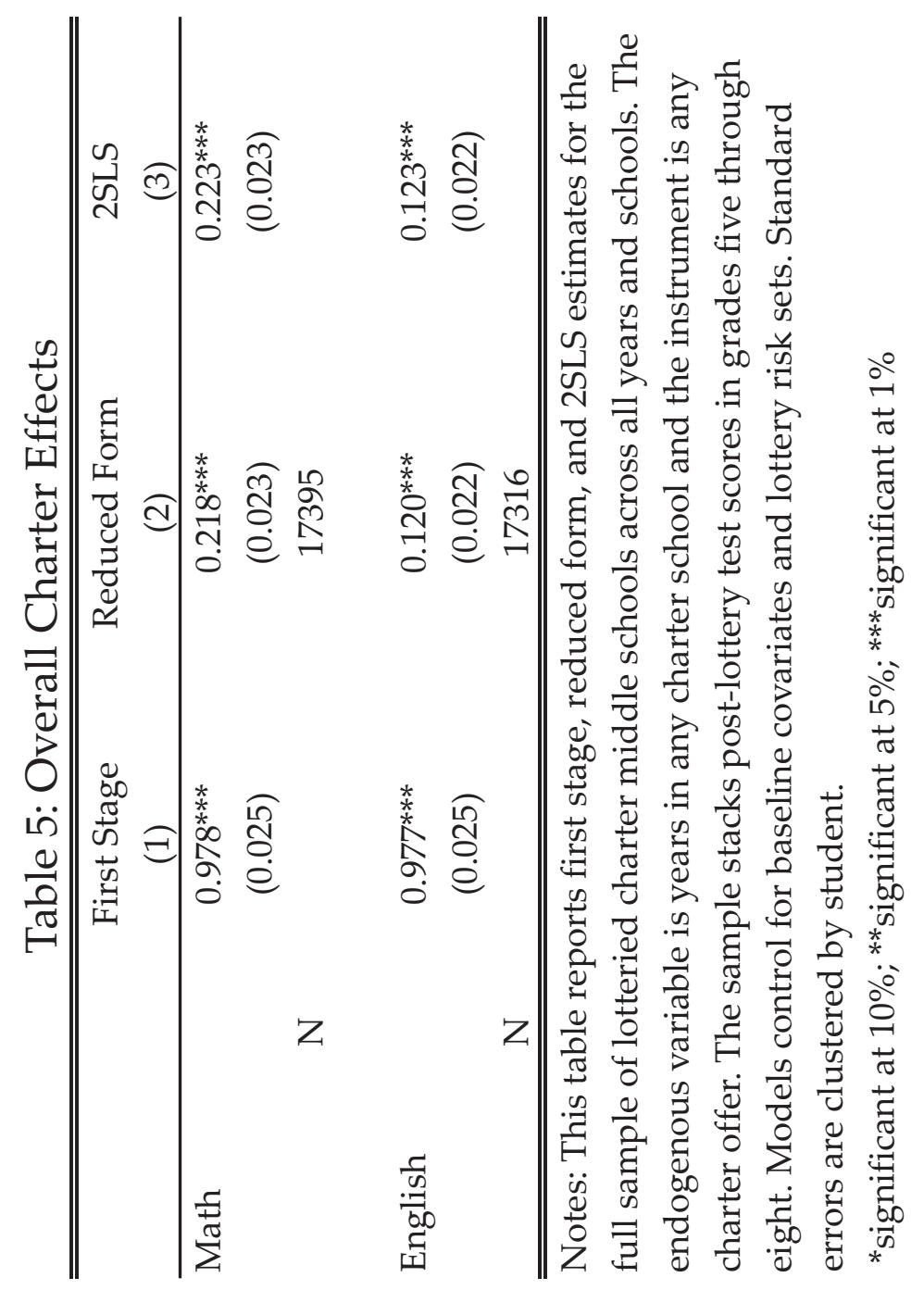




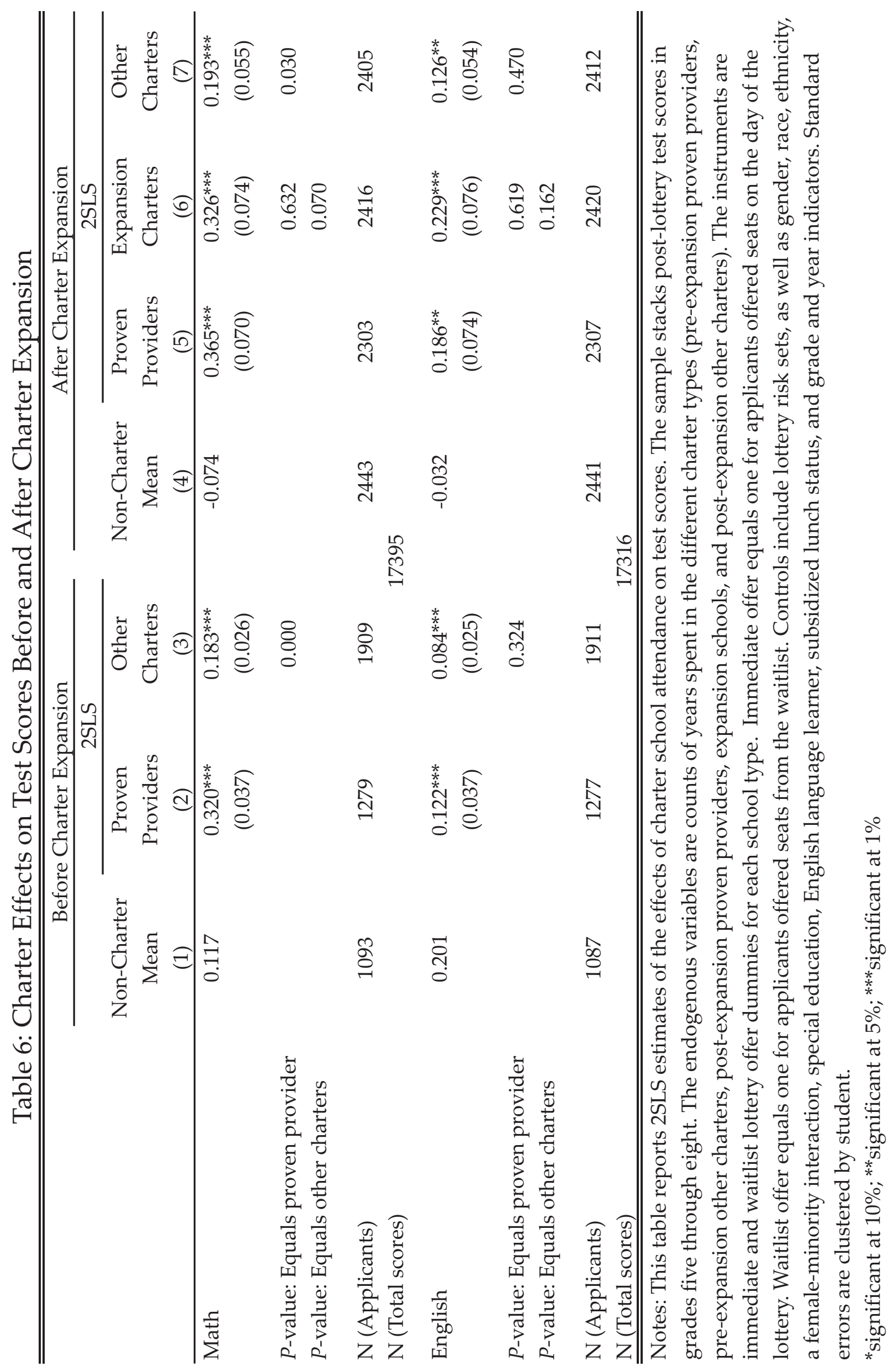


Table 7: Decomposition of Charter School Effects

\begin{tabular}{|c|c|c|c|c|c|}
\hline & \multicolumn{2}{|c|}{ Before Charter Expansion } & \multicolumn{3}{|c|}{ After Charter Expansion } \\
\hline & $\begin{array}{c}\text { Proven } \\
\text { Providers } \\
(1)\end{array}$ & $\begin{array}{c}\text { Other Charters } \\
(2)\end{array}$ & $\begin{array}{c}\text { Proven } \\
\text { Providers } \\
(3)\end{array}$ & $\begin{array}{c}\text { Expansion } \\
\text { Charters } \\
(4)\end{array}$ & $\begin{array}{c}\text { Other Charters } \\
(5)\end{array}$ \\
\hline \multicolumn{6}{|c|}{ Panel A: IV Results } \\
\hline \multicolumn{6}{|c|}{ Math } \\
\hline TOT & $\begin{array}{c}0.333^{* * *} \\
(0.029)\end{array}$ & $\begin{array}{c}0.185^{* * *} \\
(0.020)\end{array}$ & $\begin{array}{c}0.319^{* * *} \\
(0.050)\end{array}$ & $\begin{array}{c}0.359^{* * *} \\
(0.052)\end{array}$ & $\begin{array}{c}0.197^{* * *} \\
(0.037)\end{array}$ \\
\hline ATE & $\begin{array}{c}0.320^{* * *} \\
(0.030)\end{array}$ & $\begin{array}{c}0.198^{* * *} \\
(0.022)\end{array}$ & $\begin{array}{c}0.321^{* * *} \\
(0.051)\end{array}$ & $\begin{array}{c}0.345^{* * *} \\
(0.053)\end{array}$ & $\begin{array}{c}0.208^{* * *} \\
(0.038)\end{array}$ \\
\hline Match & $\begin{array}{c}0.013 \\
(0.009)\end{array}$ & $\begin{array}{l}-0.013 \\
(0.009)\end{array}$ & $\begin{array}{l}-0.002 \\
(0.008)\end{array}$ & $\begin{array}{c}0.014^{* * *} \\
(0.005)\end{array}$ & $\begin{array}{c}-0.011^{* *} \\
(0.005)\end{array}$ \\
\hline $\mathrm{N}$ (scores) & & & 15924 & & \\
\hline \multicolumn{6}{|c|}{ English } \\
\hline TOT & $\begin{array}{c}0.185^{* * *} \\
(0.030)\end{array}$ & $\begin{array}{c}0.100^{* * *} \\
(0.020)\end{array}$ & $\begin{array}{c}0.156^{* * *} \\
(0.053)\end{array}$ & $\begin{array}{c}0.207^{* * *} \\
(0.051)\end{array}$ & $\begin{array}{l}0.096^{* *} \\
(0.039)\end{array}$ \\
\hline ATE & $\begin{array}{c}0.180^{* * *} \\
(0.031)\end{array}$ & $\begin{array}{c}0.119^{* * *} \\
(0.022)\end{array}$ & $\begin{array}{c}0.144^{* * *} \\
(0.054)\end{array}$ & $\begin{array}{c}0.190^{* * *} \\
(0.052)\end{array}$ & $\begin{array}{c}0.105^{* * *} \\
(0.040)\end{array}$ \\
\hline Match & $\begin{array}{c}0.004 \\
(0.009)\end{array}$ & $\begin{array}{c}-0.019^{* *} \\
(0.009)\end{array}$ & $\begin{array}{c}0.013 \\
(0.008)\end{array}$ & $\begin{array}{c}0.016^{* * *} \\
(0.005)\end{array}$ & $\begin{array}{l}-0.009^{*} \\
(0.005)\end{array}$ \\
\hline $\mathrm{N}$ (scores) & & & 15932 & & \\
\hline \multicolumn{6}{|c|}{ Panel B: OLS Results } \\
\hline TOT & $\begin{array}{c}0.365^{* * *} \\
(0.009)\end{array}$ & $\begin{array}{c}0.234^{* * *} \\
(0.009)\end{array}$ & $\begin{array}{c}0.307^{* * *} \\
(0.011)\end{array}$ & $\begin{array}{c}0.326^{* * *} \\
(0.014)\end{array}$ & $\begin{array}{c}0.228^{* * *} \\
(0.011)\end{array}$ \\
\hline ATE & $\begin{array}{c}0.361^{* * *} \\
(0.010)\end{array}$ & $\begin{array}{c}0.258^{* * *} \\
(0.010)\end{array}$ & $\begin{array}{c}0.306^{* * *} \\
(0.011)\end{array}$ & $\begin{array}{c}0.313^{* * *} \\
(0.014)\end{array}$ & $\begin{array}{c}0.243^{* * *} \\
(0.011)\end{array}$ \\
\hline Match & $\begin{array}{c}0.003 \\
(0.003)\end{array}$ & $\begin{array}{c}-0.023^{* * *} \\
(0.003)\end{array}$ & $\begin{array}{c}0.001 \\
(0.003)\end{array}$ & $\begin{array}{c}0.013^{* * *} \\
(0.002)\end{array}$ & $\begin{array}{c}-0.015^{* * *} \\
(0.002)\end{array}$ \\
\hline $\mathrm{N}$ (scores) & & & 84246 & & \\
\hline \multicolumn{6}{|c|}{ English } \\
\hline TOT & $\begin{array}{c}0.275^{* * *} \\
(0.010)\end{array}$ & $\begin{array}{l}0.094^{* * *} \\
(0.010)\end{array}$ & $\begin{array}{c}0.203^{* * *} \\
(0.011)\end{array}$ & $\begin{array}{c}0.164^{* * *} \\
(0.013)\end{array}$ & $\begin{array}{c}0.200^{* * *} \\
(0.010)\end{array}$ \\
\hline ATE & $\begin{array}{c}0.280^{* * *} \\
(0.010)\end{array}$ & $\begin{array}{c}0.125^{* * *} \\
(0.011)\end{array}$ & $\begin{array}{c}0.191^{* * *} \\
(0.012)\end{array}$ & $\begin{array}{c}0.149^{* * *} \\
(0.013)\end{array}$ & $\begin{array}{c}0.215^{* * *} \\
(0.010)\end{array}$ \\
\hline Match & $\begin{array}{l}-0.004 \\
(0.003)\end{array}$ & $\begin{array}{c}-0.031^{* * *} \\
(0.003)\end{array}$ & $\begin{array}{c}0.012^{* * *} \\
(0.003)\end{array}$ & $\begin{array}{c}0.015^{* * *} \\
(0.002)\end{array}$ & $\begin{array}{c}-0.015^{* * *} \\
(0.002)\end{array}$ \\
\hline $\mathrm{N}$ (scores) & & & 84290 & & \\
\hline
\end{tabular}

Notes: This table decomposes estimates of charter school treatment effects into components explained and unexplained by student characteristics. These characteristics are female, black, hispanic, subsidized lunch, English language learner, special education, and baseline test scores. Estimates in panel A come from 2SLS models treating years of enrollment in each charter type and years in any charter interacted with student characteristics as endogenous, instrumenting with charter lottery offers and their interactions with student characteristics. These models control for main effects of student characteristics and lottery risk sets, and are estimated in the sample of randomized applicants. Estimates in panel B come from corresponding OLS models estimated in the full sample of Boston students. These models exclude lottery risk sets and include controls for asian, non-white other race, baseline charter attendance, and a female-minority interaction.

*significant at $10 \% ;{ }^{* *}$ significant at $5 \%$; ${ }^{* *}$ significant at $1 \%$ 


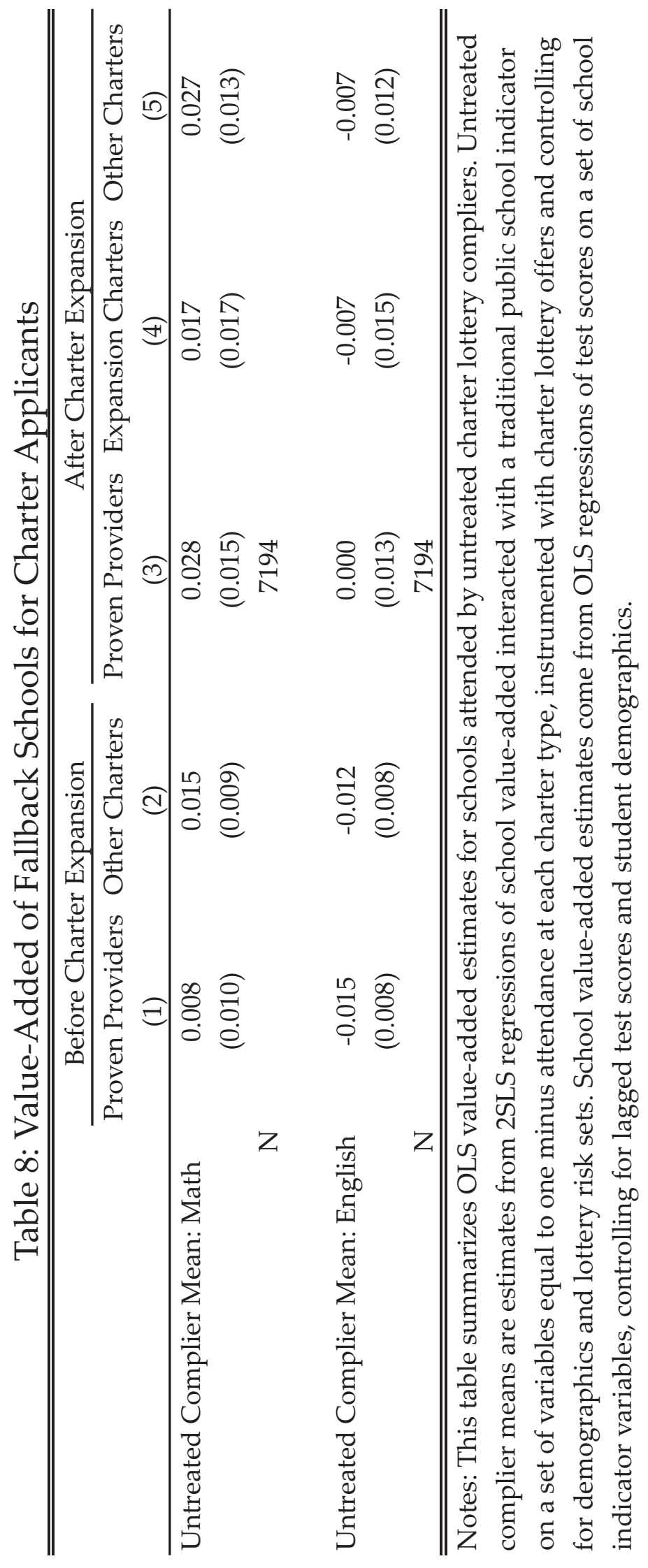




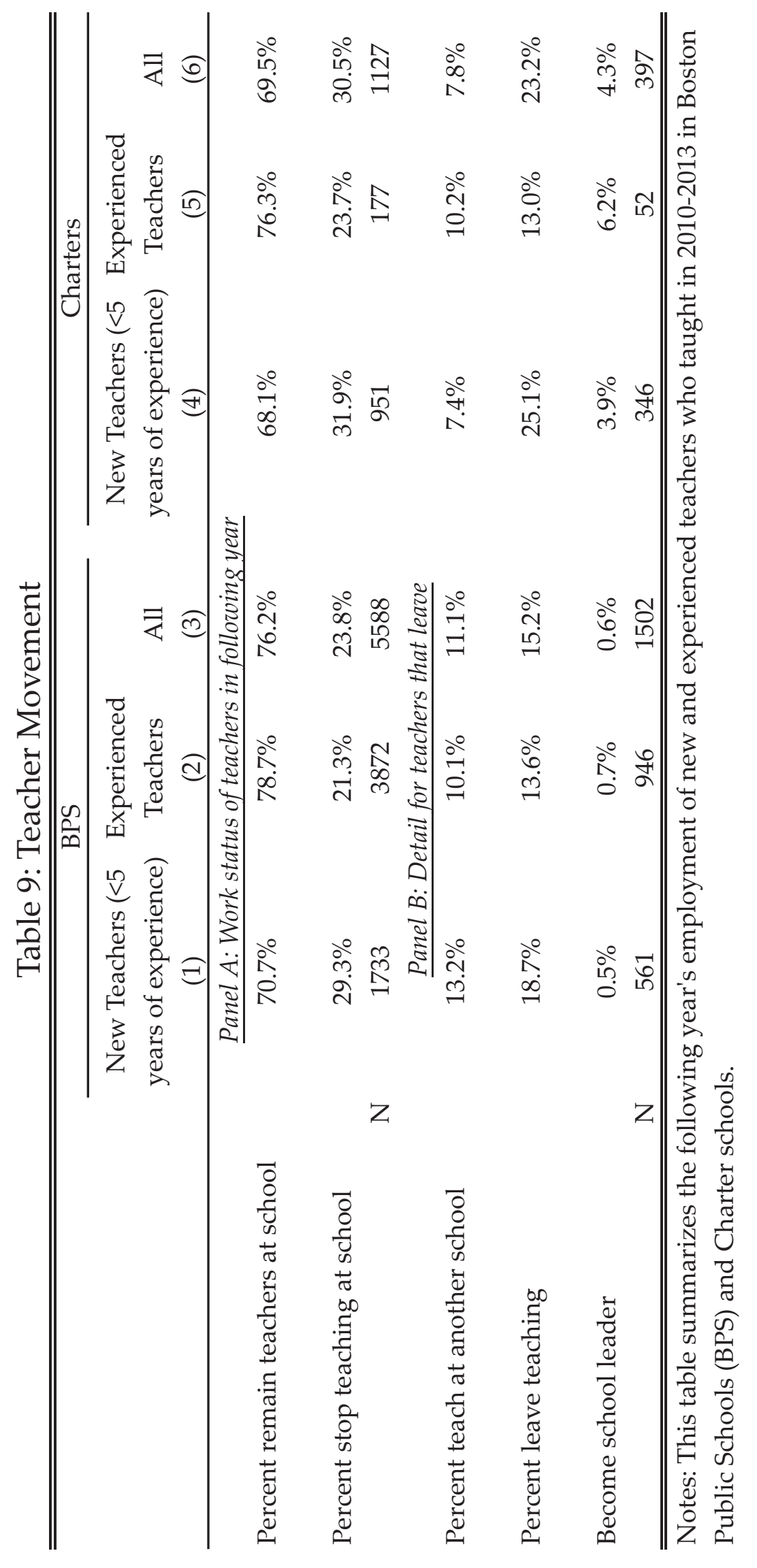




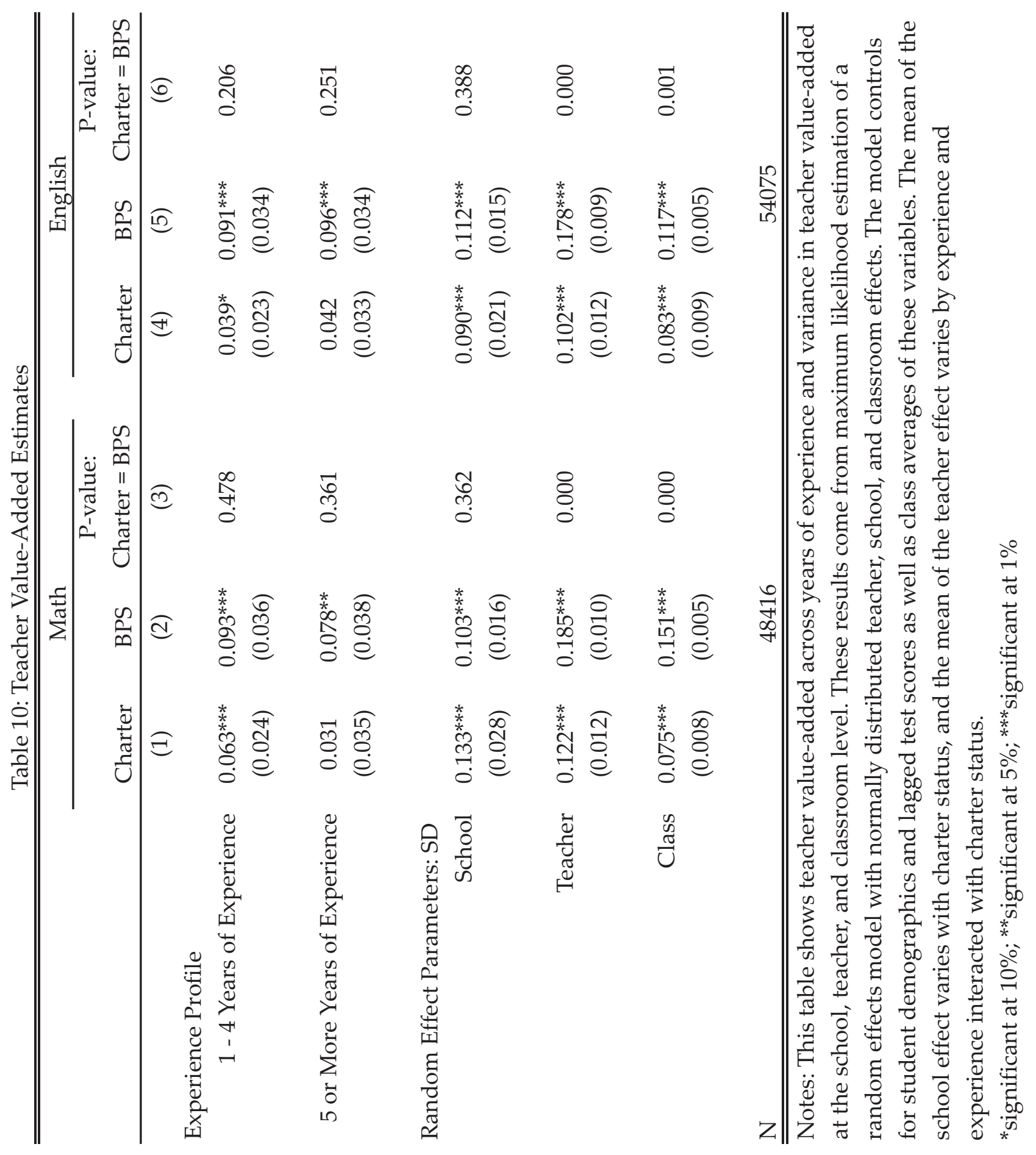




\section{REFERENCES}

Abadie, Alberto. 2002. "Bootstrap Tests for Distributional Treatment Effects in Instrumental Variables Models." Journal of the American Statistical Association 97 (457):284-292.

Abdulkadiroğlu, Atila, Joshua Angrist, Susan Dynarski, Thomas J. Kane, and Parag Pathak. 2011. "Accountability and flexibility in public schools: Evidence from Boston's charters and pilots." The Quarterly Journal of Economics 126 (2):699-748.

Abdulkadiroğlu, Atila, Joshua D. Angrist, Peter Hull, and Parag A. Pathak. 2016. "Charters Without Lotteries: Testing Takeovers in New Orleans and Boston." American Economic Review $106(7): 1878-1920$.

Abdulkadiroğlu, Atila, Joshua D. Angrist, Yusuke Narita, and Parag A. Pathak. 2017. "Research Design Meets Market Design: Using Centralized Assignment for Impact Evaluation." Econometrica 85 (5):1373-1432.

Angrist, Joshua, Parag Pathak, and Christopher Walters. 2013. "Explaining Charter School Effectiveness." American Economic Journal: Applied Economics 5 (4):1-27.

Angrist, Joshua D., Sarah R. Cohodes, Susan M. Dynarski, Parag A. Pathak, and Christopher R. Walters. 2016. "Stand and Deliver: Effects of Boston's Charter High Schools on College Preparation, Entry, and Choice." Journal of Labor Economics 34 (2):275-318.

Angrist, Joshua D, Susan M. Dynarski, Thomas J. Kane, Parag A. Pathak, and Christopher R. Walters. 2010. "Inputs and Impacts in Charter Schools: KIPP Lynn." The American Economic Review Papers and Proceedings 100.

Angrist, Joshua D., Susan M. Dynarski, Thomas J. Kane, Parag A. Pathak, and Christopher R. Walters. 2012. "Who Benefits from KIPP?" Journal of Policy Analysis and Management 31 (4):837860 .

Angrist, Joshua D., Peter D. Hull, Parag A. Pathak, and Christopher R. Walters. 2017. "Leveraging Lotteries for School Value-added: Testing and Estimation." Quarterly Journal of Economics $132(2): 871-919$.

Arsen, David and Yongmei Ni. 2012. "The effects of charter school competition on school district resource allocation." Educational Administration Quarterly 48 (1):3-38.

Banerjee, Abhijit, Rukmini Banerji, James Berry, Esther Duflo, Harini Kannan, Shobhini Mukerji, Marc Shotland, and Michael Walton. 2017. "From Proof of Concept to Scalable Policies: Challenges and Solutions, with an Application." Journal of Economic Perspectives 31 (4):73-102. URL http://www . aeaweb.org/articles?id=10.1257/jep.31.4.73.

Betts, Julian R. 2009. "The competitive effects of charter schools on traditional public schools." Handbook of research on school choice :195-208.

Bifulco, Robert and Randall Reback. 2014. "Fiscal impacts of charter schools: lessons from New York." Education Finance and Policy 9 (1):86-107.

Blinder, Alan S. 1973. "Wage discrimination: reduced form and structural estimates." Journal of Human Resources 8 (4):436-455. 
Bold, Tessa, Mwangi Kimenyi, Germano Mwabu, Justin Sandefur et al. 2018. "Experimental evidence on scaling up education reforms in Kenya." Journal of Public Economics 168:1-20.

Booker, Kevin, Scott M Gilpatric, Timothy Gronberg, and Dennis Jansen. 2008. "The effect of charter schools on traditional public school students in Texas: Are children who stay behind left behind?" Journal of Urban Economics 64 (1):123-145.

Borman, Geoffrey D., Robert E. Slavin, Alan C. K. Cheung, Anne M. Chamberlain, Nancy A. Madden, and Bette Chambers. 2007. "Final Reading Outcomes of the National Randomized Field Trial of Success for All." American Educational Research Journal 44 (3):701-731.

Boston Municipal Research Bureau. 2008. "The Status of Charter Schools in Boston." Available at http://bmrb.org/wp-content/uploads/2014/10/Charter608.pdf.

Carter, Samuel Casey. 2000. No Excuses: Lessons from 21 High-Performing, High-Poverty Schools. Washington, DC: Heritage Foundation.

Chabrier, Julia, Sarah Cohodes, and Philip Oreopoulos. 2016. "What Can We Learn from Charter School Lotteries." Journal of Economic Perspectives 30 (3):57-84.

Chamberlain, Gary. 1982. "Multivariate Regression Models for Panel Data." Journal of Econometrics $18(1): 5-46$.

Chetty, Raj, John N. Friedman, and Jonah E. Rockoff. 2014. "Measuring the Impacts of Teachers I: Evaluating Bias in Teacher Value-added Estimates." American Economic Review 104 (9):25932632.

Clotfelter, Charles, Helen Ladd, and Jacob Vigdor. 2007. "How and why do teacher credentials matter for student achievement?" NBER Working Paper No 12828.

Cohodes, Sarah R., Elizabeth M. Setren, Christopher R. Walters, Joshua D. Angrist, and Parag A. Pathak. 2013. "Charter School Demand and Effectiveness: a Boston Update." Boston, MA: The Boston Foundation, October.

Cook, Jason B. 2018. "The effect of charter competition on unionized district revenues and resource allocation." Journal of Public Economics 158:48-62.

Cordes, Sarah A. 2018. "In pursuit of the common good: The spillover effects of charter schools on public school students in New York City." Education Finance and Policy 13 (4):484-512.

David, Rebecca. 2018. "National Charter School Management Overview: 2016-17 School Year." Tech. rep., National Alliance for Public Charter Schools.

David, Rebecca, Kevin Hesla, and Susan Aud Pendergrass. 2017. "A Growing Movement: America's Largest Public Charter School Communitieis." Tech. rep., National Alliance for Public Charter Schools.

Davis, Jonathan, Jonathan Guryan, Kelly Hallberg, and Jens Ludwig. 2017. "The Economics of Scale-Up." Tech. Rep. Working Paper No. 23925, National Bureau of Economic Research.

Davis, Tomeka M. 2013. "Charter school competition, organization, and achievement in traditional public schools." education policy analysis archives 21:88. 
Dobbie, Will and Roland Fryer. 2011. "Are High Quality Schools Enough to Increase Achievement Among the Poor?" American Economic Journal: Applied Economics 3 (3):158-187.

- 2013. "Getting Beneath the Veil of Effective Schools: Evidence from New York City." American Economic Journal: Applied Economics 5 (4):28-60.

—. 2015. "The Medium-Term Impacts of High-Achieving Charter Schools." Journal of Political Economy 123 (5):985-1037.

Duflo, Esther, Pascaline Dupas, and Michael Kremer. 2011. "Peer Effects, Teacher Incentives, and the Impact of Tracking: Evidence from a Randomized Evaluation in Kenya." American Economic Review 101 (5):1739-74. URL http://www . aeaweb.org/articles?id=10.1257/aer.101.5.1739.

. 2015. "School governance, teacher incentives, and pupil-teacher ratios: Experimental evidence from Kenyan primary schools." Journal of Public Economics 123:92-110.

Epple, Dennis, Richard Romano, and Ron Zimmer. 2016. "Charter schools: A survey of research on their characteristics and effectiveness." In Handbook of the Economics of Education, vol. 5. Elsevier, 139-208.

Fryer, Roland. 2014. "Injecting Charter School Best Practices Into Traditional Public Schools: Evidence from Field Experiments." Quarterly Journal of Economics 129 (3):1355-1407.

Furgeson, Joshua, Brian Gill, Joshua Haimson, Alexandra Killewald, Moira McCullough, Ira Nichols-Barrer, Bing-ru Teh, Natalya Verbitsky-Savitz, Melissa Bowen, Allison Demeritt et al. 2011. "The National Study of Charter Management Organization (CMO) Effectiveness. CharterSchool Management Organizations: Diverse Strategies and Diverse Student Impacts." Mathematica Policy Research, Inc. .

Gabbianelli, Leslie, Kate McGovern, and Melissa Wu. 2014. "Greenhouse Schools in Boston: School Leadership Practices Across a High-Performing Charter Sector." Tech. rep., The New Teacher Project.

Gill, Brian. 2016. "The effect of charter schools on students in traditional public schools: A review of the evidence." Education Next.

Gill, Brian and Kevin Booker. 2008. "School competition and student outcomes." Handbook of research in education finance and policy :183-200.

Hanushek, Eric A. and Steven G. Rivkin. 2010. "Generalizations about Using ValueAdded Measures of Teacher Quality." American Economic Review 100 (2):267-71. URL http://www. aeaweb.org/articles?id=10.1257/aer.100.2.267.

Harris, Doug. 2011. "Teacher training, teacher quality and student achievement." Journal of Public Economics 95 (7-8):798-812.

Heckman, James, Seong Hyeok Moon, Rodrigo Pinto, Peter A. Savelyev, and Adam Yavitz. 2010. "Analyzing Social Experiments as Implemented: A Reexamination of the Evidence from the High/ Scope Perry Preschool Program." Quantitative Economics 1 (1):1-46.

Heckman, James, Rodrigo Pinto, and Peter Savelyev. 2013. "Understanding the Mechanisms Through Which an Influential Early Childhood Program Boosted Adult Outcomes." American Economic Review 103 (6):2052-2086. 
Imberman, Scott A. 2011. "The effect of charter schools on achievement and behavior of public school students." Journal of Public Economics 95 (7-8):850-863.

Jackson, C. Kirabo and Elias Bruegmann. 2009. "Teaching Students and Teaching Each Other: The Importance of Peer Learning for Teachers." American Economic Journal: Applied Economics 1 (4):85-108. URL http://www.jstor.org/stable/25760183.

Jackson, C. Kirabo and Alexey Makarin. 2018. "Can Online Off-The-Shelf Lessons Improve Student Outcomes? Evidence from A Field Experiment." American Economic Journal: Economic Policy 10 (3). Https://www.aeaweb.org/articles?id=10.1257/pol.20170211.

Jepsen, Christopher and Steven Rivkin. 2009. "Class Size Reduction and Student Achievement: The Potential Tradeoff between Teacher Quality and Class Size." The Journal of Human Resources 44 (1):223-250.

Jinnai, Yusuke. 2014. "Direct and indirect impact of charter schools' entry on traditional public schools: New evidence from North Carolina." Economics Letters 124 (3):452-456.

Kane, Thomas J., Jonah E. Rockoff, and Douglas O. Staiger. 2008. "What Does Certification Tell Us About Teacher Effectiveness? Evidence from New York City." Economics of Education Review $27: 615-631$.

Krueger, Alan. 1999. "Experimental Estimates of Education Production Functions." Quarterly Journal of Economics 114 (2):497-532.

Ladd, Helen and John D. Singleton. 2018. "The Fiscal Externalities of Charter Schools: Evidence from North Carolina." Tech. Rep. Working Paper 182, National Center for Analysis of Longitudinal Data in Education Research.

Massachusetts Department of Elementary and Secondary Education. 2015. "Education Laws and Regulations 603 CMR 1.00: Charter Schools." Available at http://www.doe.mass.edu/lawsregs/603cmr1.html.

- 2016. "Massachusetts Charter Schools Fact Sheet." Available at http://www.doe.mass.edu/charter/factsheet.pdf.

Massachusetts State Legislature. 2010. "An Act Relative to the Achievement Gap." Chapter 12.

Mundlak, Yair. 1978. "On the Pooing of Time Series and Cross Section Data." Econometrica 46 (1):69-85.

New York State Department of Education. 2019. "New York Charter School Fact Sheet." http://www.p12.nysed.gov/psc/facts/nyscsfactsheet1042019.pdf.

Oaxaca, Ronald. 1973. "Male-female wage differentials in urban labor markets." International Economic Review 14 (3):693-709.

Papay, John and Matt Kraft. 2015. "Productivity returns to experience in the teacher labor market: Methodological challenges and new evidence on long-term career improvement." Journal of Public Economics 130:105-119. 
Papay, John P., Eric S. Taylor, John H. Tyler, and Mary Laski. 2016. "Learning Job Skills from Colleagues at Work: Evidence from a Field Experiment Using Teacher Performance Data." Working Paper 21986, National Bureau of Economic Research. URL http://www. nber.org/papers/w21986. DOI: 10.3386/w21986.

Puma, Michael, Stephen Bell, and Camilla Heid. 2012. "Third Grade Follow-up to the Head Start Impact Study." OPRE Report 2012-45. U.S. Department of Health and Human Services. Washington, DC, October.

Quint, Janet, Pei Zhu, Rekha Balu, Shelley Rappaport, and Micah DeLaurentis. 2015. "Scaling Up the Sucess for All Model of School Reform." MDRC Report, September.

Ridley, Matthew and Camille Terrier. 2018. "Fiscal and Education Spillovers from Charter School Expansion." Tech. Rep. SEII Discussion Paper 2018.02, School Effectiveness and Inequality Initiative.

Rockoff, Jonah. 2004. "The impact of individual teachers on student achievement. Evidence from panel data." American Economic Review 94 (2):247-252.

Ronfeldt, Matthew, Susanna Owens Farmer, Kiel McQueen, and Jason A. Grissom. 2015. "Teacher Collaboration in Instructional Teams and Student Achievement." American Educational Research Journal 52 (3):475-514. URL https://doi.org/10.3102/0002831215585562.

Sass, Tim R. 2006. "Charter schools and student achievement in Florida." Education Finance and Policy 1 (1):91-122.

Setren, Elizabeth M. 2016. "Special Education and English Language Learner Students in Boston Charter Schools: Impact and Classification." School Effectiveness \& Inequality Initiative Working Paper 2016.06, October.

Shin, Hyo Jeong, Bruce Fuller, and Luke Dauter. 2017. "Heterogeneous Effects of Charter Schools: Unpacking Family Selection and Achievement Growth in Los Angeles." Journal of School Choice 11 (1):60-94. URL https://doi.org/10.1080/15582159.2016.1238278.

Sun, Min, Susanna Loeb, and Jason A. Grissom. $2017 . \quad$ "Building Teacher Teams: Evidence of Positive Spillovers From More Effective Colleagues." Educational Evaluation and Policy Analysis 39 (1):104-125. URL http://journals. sagepub. com. ezproxy. cul . columbia. edu/doi/abs/10.3102/0162373716665698.

Taylor, Eric S. 2018. "New Technology and Teacher Productivity." Tech. rep., Harvard University. Unpublished manuscript.

Thernstrom, Abigail and Stephen Thernstrom. 2003. No Excuses: Closing the Racial Gap in Learning. New York: Simon and Schuster.

Tuttle, Christina Clark, Brian Gill, Philip Gleason, Virginia Knechtel, Ira Nichols-Barrer, and Alexandra Resch. 2013. "KIPP Middle Schools: Impact on Achievement and Other Outcomes." Mathematica Policy Research Report 06441.910, February.

Tuttle, Christina Clark, Philip Gleason, Virginia Knechtel, Ira Nichols-Barrer, Kevin Booker, Gregory Chojnacki, Thomas Coen, and Goble Lisbeth. 2015. "Understanding the Effect of KIPP as it Scales: Volume I, Impacts on Achievement and Other Outcomes." Mathematica Policy Research Report . 
Walters, Christopher R. 2018. "The Demand for Effective Charter Schools." Journal of Political Economy 126 (6).

Winters, Marcus A. 2012. "Measuring the effect of charter schools on public school student achievement in an urban environment: Evidence from New York City." Economics of Education review $31(2): 293-301$.

Ziebarth, Todd and Louann Bierlein Palmer. 2018. "Measuring up to the model: A ranking of state public charter school laws." Tech. rep., National Alliance for Public Charter Schools.

Zimmer, Ron and Richard Buddin. 2009. "Is charter school competition in California improving the performance of traditional public schools?" Public Administration Review 69 (5):831-845.

Zimmer, Ron, Brian Gill, Kevin Booker, Stephane Lavertu, and Tim R Sass. 2009. Charter schools in eight states: Effects on achievement, attainment, integration, and competition. Rand Corporation. 


\section{Data Appendix}

We use lottery records, student demographic and enrollment data, state standardized test scores, and school personnel files in this article. Lottery records collected from individual schools contain the list of applicants, offer status, and factors that affect an applicant's lottery odds, including sibling status, disqualifications, late applications, and applying from outside of Boston. The Student Information Management Systems (SIMS) dataset contains enrollment and demographic data for all public school students in Massachusetts. Student standardized test scores come from the state database for the Massachusetts Comprehensive Assessment System (MCAS). The Massachusetts Education Personnel Information Management Systems (EPIMS) database provides school staff information. Next we describe these datasets, the matching process, and sample construction.

\section{Lottery records}

Massachusetts legally requires charters to admit students via lottery when more students apply to a charter school than the number of available seats for a given grade. Our paper uses records from charter lotteries conducted between spring 2004 to spring 2013 for 14 charter schools accepting students in 5 th or 6 th grade. Each of the 14 schools contributes oversubscribed lottery data. ${ }^{22}$ Schools vary in the grades they serve and in years of operation. Table A1 lists this information and the years each school contributes to the analysis. We exclude one school that did not provide lottery records (Smith Leadership Academy) and two schools that closed before the charter expansion (Uphams Corner Charter School in 2009 and Fredrick Douglas Charter School in 2005). Lottery data typically includes applicants' names, dates of birth, and lottery and waitlist offer status. Offers to attend charter schools either occur on the day of the lottery (referred to as immediate offer) or after the day of the lottery when students receive offers from the randomly sequenced waitlist as seats become available. In three out of the 65 lotteries in the study, the schools gave all applicants offers or did not give waitlist offers to non-siblings. Four lotteries did not distinguish the timing of the offers so we code the immediate offer variable to equal zero for these cohorts.

The Uncommon Schools/Roxbury Preparatory charter network held a single lottery for its three

\footnotetext{
${ }^{22}$ We do not have Spring 2004 lottery records for Brooke Roslindale, Boston Prep, and Academy of the Pacific Rim or Spring 2005 records for Brooke Roslindale. Brooke Roslindale does not have lotteries in after charter expansion because their elementary school students filled the middle school seat. All other schools and years have oversubscribed lottery data.
} 
campuses in the Spring 2012 and Spring 2013 lotteries. When the school called a students lottery number, the student could pick from the campuses that still had open seats. Our lottery records show which campus they picked at the time of the lottery. We find the last lottery number for each campus and code all students with better lottery numbers as having offers from that campus.

Uncommon Schools offered seats from the waitlist as they became available for individual campuses. Parents chose to accept or decline waitlist offers for single schools. If they declined, they were taken off the waitlist and would not be considered for seats at the other campuses.

\section{Enrollment and demographics}

The SIMS data contains individual level data for students enrolled in public schools in Massachusetts from 2003-2004 through 2013-2014. The data contains snapshots from October and the end of the school year. Each student has only one observation in each time period, except when students switch grades or schools within year. Fields include a unique student identifier, grade level, year, name, date of birth, gender, ethnicity, special education status, limited English proficiency status, free or reduced price lunch status, school attended, suspensions, attendance rates, and days truant.

We code students as charter attendees in a school year if they attended a charter at any point

during a year. Students who attend more than one charter school in a year are assigned to the charter they attended the longest. Students who attend more than one traditional public school and no charter schools in a year are assigned to the school they attended the longest. We randomly choose between schools if students have attendance ties between the most attended schools.

\section{Test scores}

This paper uses individual student math and English Language Arts (ELA) Massachusetts Comprehensive Assessment System (MCAS) test scores from 2003-2004 through 2013-2014. Massachusetts public school students take the exam each year in grades grades 5 through 8 . Data includes the unique student identifier. We standardize the raw scores to to have a mean of zero within subject-grade-year in Boston.

\section{Staff records}

The Education Personnel Information Management Systems (EPIMS) contains yearly staff level data for all employees in Massachusetts public schools. We use data collected in October of the 
2007-08 through the 2013-14 school years. Data includes job position, school, full time equivalency, date of birth, date of hire for first public school job in Massachusetts, license status, and highly qualified status. We use the full time equivalency of all staff and teachers. If one school has two half time teachers, they are counted as one full time equivalent teacher. A teacher who teaches at multiple schools counts towards the staff statistics at each school.

\section{Matching data}

We use applicants' names, date of birth, grade, and year to match their lottery records to the state enrollment data. The applicants who uniquely and exactly match the grade, year, name, and date of birth (if available) in the state records are assigned to the matched unique student id. After this initial match, we strip names in the lottery and enrollment data of spaces, surnames, hyphens, and apostrophes. Unique matches after this cleaning are assigned to the matched unique student id. Then, we use reclink, a fuzzy matching STATA program, to suggest potential matches for the remaining students. This matches students with slight spelling differences and those who appear in one grade older or younger than the charter application grade. We hand check these suggested matches for accuracy. We search for the remaining unmatched students by hand in the data. Typically this last group contains name truncations, name misspellings, or first and last names in the wrong field.

The matching process assigns 95 percent of applicants to the state administrative records (see Table A3). Students who do not match either enroll in private, parochial, or out-of-state schools, have names and birthdates too common to match, or have spelling errors too extreme to match with confidence. Receiving a charter offer makes students 3.8 more likely to match to the data, as shown

in Table A3. As a result, our findings show causal estimates for the set of students who enroll in Massachusetts Public Schools.

We match the enrollment and demographic data to the student test scores using the unique student identifier. Students who attend out of state, private, or parochial schools do not have test score outcomes for their years outside of Massachusetts public schools.

\section{Sample restrictions}

We exclude applicants who receive higher or lower preference in the lottery. Late applicants, those who apply to the wrong grade, out-of-area applicants, and siblings fall into these categories 
and typically have no variation in offer status. When students have duplicate applications within an individual school's lottery, we keep only one application. If students apply to charter schools in different years, we use only the first application year. We restrict the sample to students with baseline demographics data, excluding students applying from outside of Massachusetts public schools. With these restrictions imposed, the original raw sample of applications narrows from 20,981 to 8,473 . 


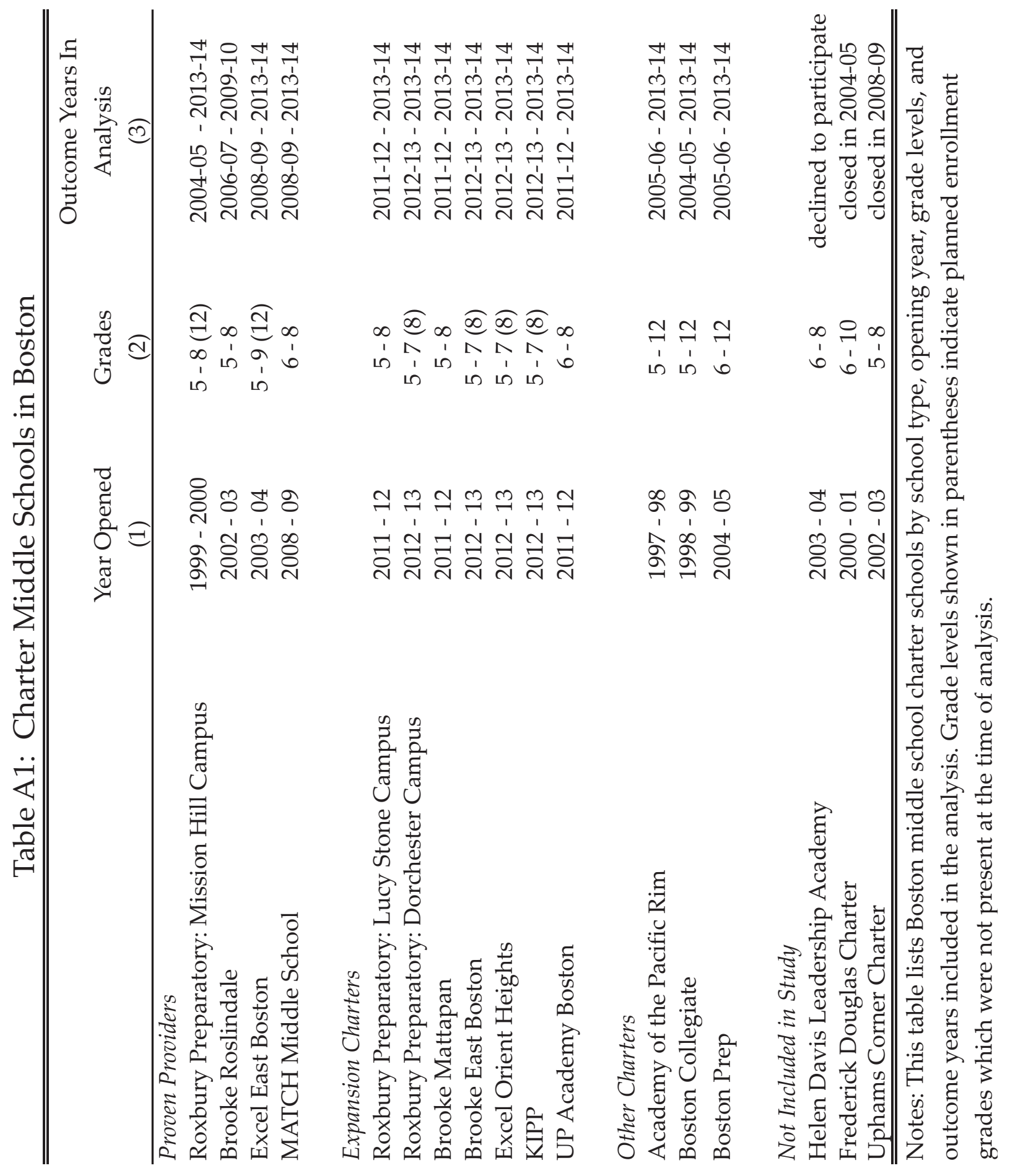




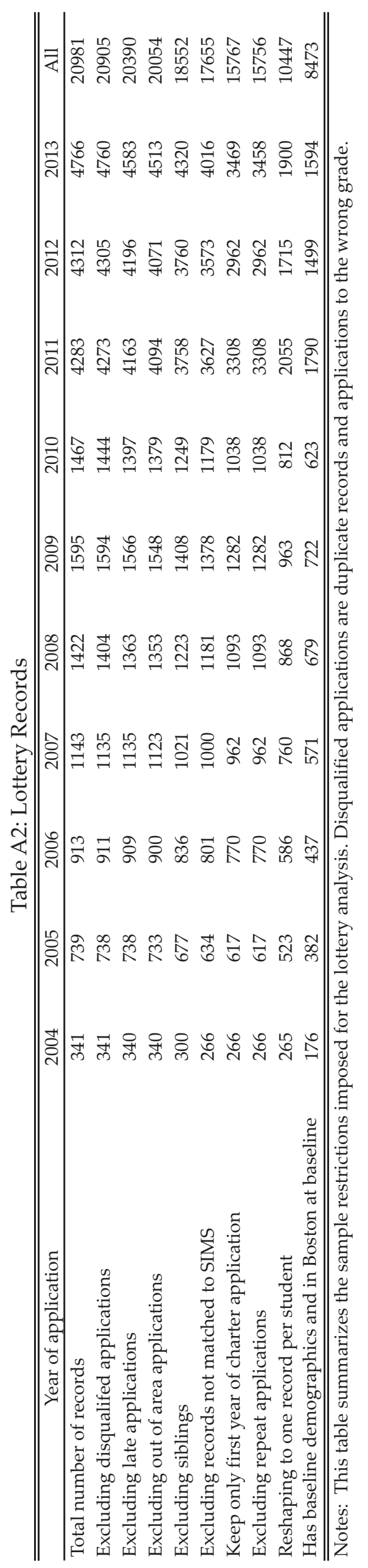


Table A3: Match from Lottery Data to Administrative Data

\begin{tabular}{|c|c|c|c|c|}
\hline \multirow[b]{2}{*}{ Lottery Year } & \multirow{2}{*}{$\begin{array}{c}\text { Number of } \\
\text { Applications } \\
\text { (1) }\end{array}$} & \multirow{2}{*}{$\begin{array}{c}\text { Proportion } \\
\text { Matched } \\
(2)\end{array}$} & \multicolumn{2}{|c|}{ Regression of Match on Offer } \\
\hline & & & $\begin{array}{c}\text { Immediate Offer } \\
(3)\end{array}$ & $\begin{array}{c}\text { Any Offer } \\
(4)\end{array}$ \\
\hline 2004 & 268 & 0.989 & $\begin{array}{l}-0.006 \\
(0.026)\end{array}$ & $\begin{array}{l}-0.007 \\
(0.013)\end{array}$ \\
\hline 2005 & 616 & 0.987 & $\begin{array}{l}- \\
-\end{array}$ & $\begin{array}{c}0.002 \\
(0.013)\end{array}$ \\
\hline 2006 & 742 & 0.991 & - & $\begin{array}{c}0.004 \\
(0.016)\end{array}$ \\
\hline 2007 & 924 & 0.984 & $\begin{array}{l}0.019^{* *} \\
(0.008)\end{array}$ & $\begin{array}{l}0.034^{* * *} \\
(0.013)\end{array}$ \\
\hline 2008 & 1018 & 0.957 & $\begin{array}{l}0.042^{* * *} \\
(0.013)\end{array}$ & $\begin{array}{l}0.061^{* * *} \\
(0.019)\end{array}$ \\
\hline 2009 & 1106 & 0.977 & $\begin{array}{c}0.004 \\
(0.011)\end{array}$ & $\begin{array}{c}0.011 \\
(0.010)\end{array}$ \\
\hline 2010 & 1041 & 0.924 & $\begin{array}{l}0.065^{* * *} \\
(0.016)\end{array}$ & $\begin{array}{c}0.071^{* * *} \\
(0.017)\end{array}$ \\
\hline 2011 & 2614 & 0.954 & $\begin{array}{c}0.018^{* * *} \\
(0.007)\end{array}$ & $\begin{array}{c}0.025^{* * *} \\
(0.007)\end{array}$ \\
\hline 2012 & 2503 & 0.939 & $\begin{array}{c}0.001 \\
(0.011)\end{array}$ & $\begin{array}{c}0.033^{* * *} \\
(0.011)\end{array}$ \\
\hline 2013 & 2712 & 0.902 & $\begin{array}{c}0.045^{* * *} \\
(0.012)\end{array}$ & $\begin{array}{c}0.078^{* * *} \\
(0.015)\end{array}$ \\
\hline All Cohorts & 15482 & 0.949 & $\begin{array}{c}0.023^{* * *} \\
(0.003)\end{array}$ & $\begin{array}{c}0.038^{* * *} \\
(0.004)\end{array}$ \\
\hline
\end{tabular}

Notes: This table summarizes the match from the lottery records to administrative student data. The sample excludes late applicants, siblings, disqualified applicants, duplicate names, and out-of-area applicants. Columns (3) and (4) report coefficients from regressions on a dummy for a successful match on immediate and any charter offer dummies. All regressions control for school-by-year dummies.

${ }^{*}$ significant at $10 \% ;{ }^{* *}$ significant at $5 \% ;{ }^{* * *}$ significant at $1 \%$ 


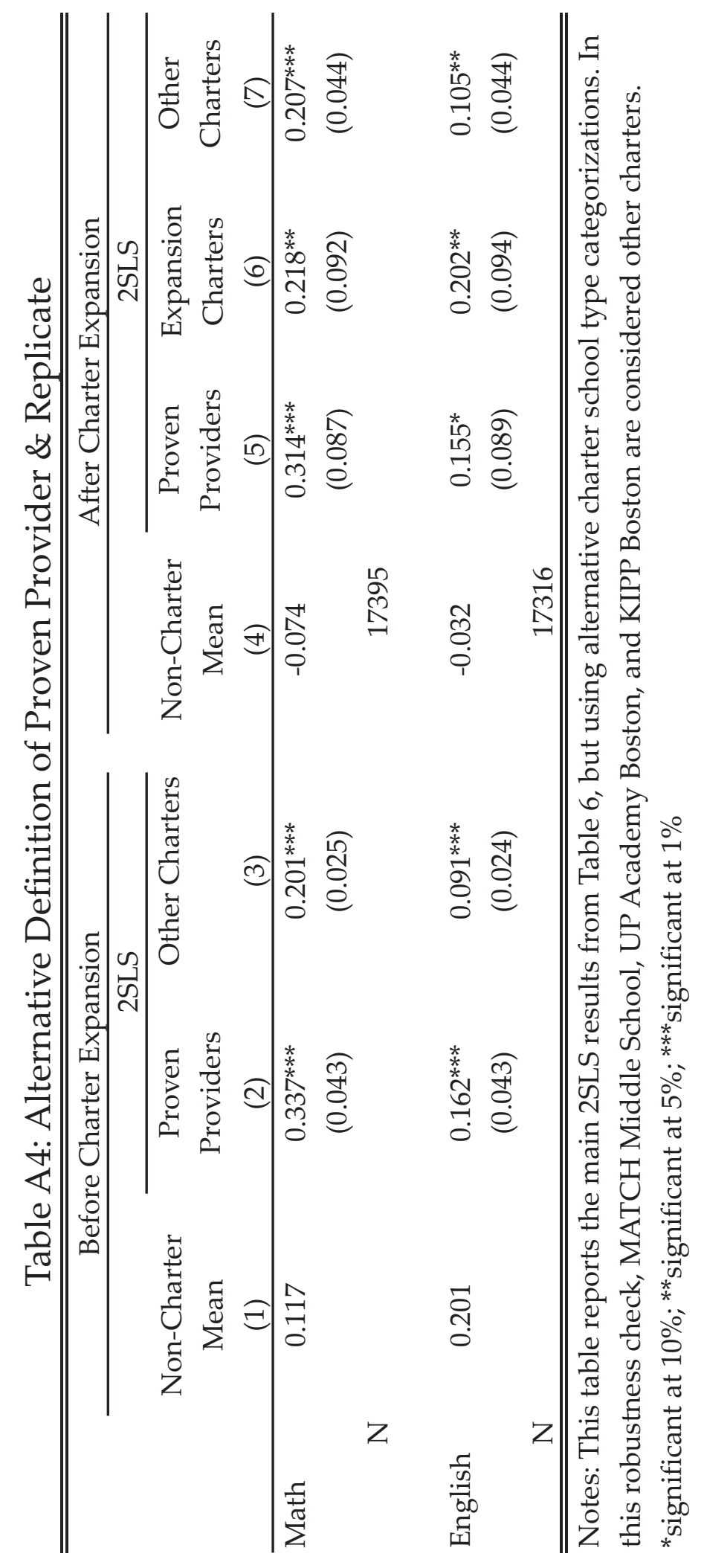


Table A5: Covariate Balance

\begin{tabular}{|c|c|c|c|c|c|}
\hline & \multicolumn{2}{|c|}{ Before Charter Expansion } & \multicolumn{3}{|c|}{ After Charter Expansion } \\
\hline & $\begin{array}{c}\text { Proven } \\
\text { Providers } \\
(1)\end{array}$ & $\begin{array}{c}\text { Other } \\
\text { Charters } \\
(2)\end{array}$ & $\begin{array}{c}\text { Proven } \\
\text { Providers } \\
\text { (3) }\end{array}$ & $\begin{array}{c}\text { Expansion } \\
\text { Schools } \\
(4)\end{array}$ & $\begin{array}{c}\text { Other Charters } \\
\text { (5) }\end{array}$ \\
\hline Female & $\begin{array}{c}0.000 \\
(0.034)\end{array}$ & $\begin{array}{l}-0.004 \\
(0.028)\end{array}$ & $\begin{array}{l}-0.005 \\
(0.027)\end{array}$ & $\begin{array}{c}0.011 \\
(0.027)\end{array}$ & $\begin{array}{c}0.020 \\
(0.028)\end{array}$ \\
\hline Black & $\begin{array}{l}-0.026 \\
(0.032)\end{array}$ & $\begin{array}{c}0.007 \\
(0.027)\end{array}$ & $\begin{array}{l}-0.027 \\
(0.027)\end{array}$ & $\begin{array}{l}-0.025 \\
(0.026)\end{array}$ & $\begin{array}{l}-0.015 \\
(0.028)\end{array}$ \\
\hline Latino/a & $\begin{array}{c}0.027 \\
(0.031)\end{array}$ & $\begin{array}{c}0.000 \\
(0.022)\end{array}$ & $\begin{array}{l}-0.001 \\
(0.027)\end{array}$ & $\begin{array}{c}0.005 \\
(0.026)\end{array}$ & $\begin{array}{l}-0.010 \\
(0.027)\end{array}$ \\
\hline Asian & $\begin{array}{l}-0.014 \\
(0.009)\end{array}$ & $\begin{array}{c}0.007 \\
(0.008)\end{array}$ & $\begin{array}{c}0.008 \\
(0.010)\end{array}$ & $\begin{array}{c}0.010 \\
(0.011)\end{array}$ & $\begin{array}{c}0.000 \\
(0.009)\end{array}$ \\
\hline White & $\begin{array}{c}0.016 \\
(0.011)\end{array}$ & $\begin{array}{l}-0.003 \\
(0.024)\end{array}$ & $\begin{array}{c}0.007 \\
(0.010)\end{array}$ & $\begin{array}{c}0.001 \\
(0.012)\end{array}$ & $\begin{array}{c}0.018 \\
(0.017)\end{array}$ \\
\hline Subsidized Lunch & $\begin{array}{c}0.015 \\
(0.029)\end{array}$ & $\begin{array}{c}0.010 \\
(0.027)\end{array}$ & $\begin{array}{l}-0.011 \\
(0.020)\end{array}$ & $\begin{array}{l}-0.016 \\
(0.019)\end{array}$ & $\begin{array}{l}-0.016 \\
(0.023)\end{array}$ \\
\hline English Language Learners & $\begin{array}{l}-0.005 \\
(0.023)\end{array}$ & $\begin{array}{l}-0.001 \\
(0.014)\end{array}$ & $\begin{array}{l}-0.004 \\
(0.027)\end{array}$ & $\begin{array}{l}-0.039 \\
(0.026)\end{array}$ & $\begin{array}{l}-0.027 \\
(0.025)\end{array}$ \\
\hline Special Education & $\begin{array}{l}-0.005 \\
(0.027)\end{array}$ & $\begin{array}{c}0.005 \\
(0.022)\end{array}$ & $\begin{array}{c}0.002 \\
(0.021)\end{array}$ & $\begin{array}{c}0.013 \\
(0.022)\end{array}$ & $\begin{array}{c}0.018 \\
(0.022)\end{array}$ \\
\hline Attended charter before applying & $\begin{array}{c}0.010 \\
(0.019)\end{array}$ & $\begin{array}{l}-0.008 \\
(0.020)\end{array}$ & $\begin{array}{l}-0.015 \\
(0.010)\end{array}$ & $\begin{array}{l}-0.015^{*} \\
(0.008)\end{array}$ & $\begin{array}{l}-0.003 \\
(0.014)\end{array}$ \\
\hline Baseline math score & $\begin{array}{l}-0.024 \\
(0.071)\end{array}$ & $\begin{array}{l}-0.022 \\
(0.053)\end{array}$ & $\begin{array}{c}0.058 \\
(0.050)\end{array}$ & $\begin{array}{l}-0.033 \\
(0.051)\end{array}$ & $\begin{array}{l}-0.004 \\
(0.055)\end{array}$ \\
\hline Baseline English score & $\begin{array}{l}-0.036 \\
(0.071)\end{array}$ & $\begin{array}{c}0.000 \\
(0.052)\end{array}$ & $\begin{array}{c}0.048 \\
(0.053)\end{array}$ & $\begin{array}{c}0.037 \\
(0.051)\end{array}$ & $\begin{array}{c}0.011 \\
(0.055)\end{array}$ \\
\hline $\mathrm{N}$ (offered) & 1009 & 1309 & 1466 & 1825 & 1142 \\
\hline P-value & 0.594 & 0.891 & 0.526 & 0.136 & 0.979 \\
\hline
\end{tabular}

Notes: This table reports coefficients from regressions of baseline characteristics on charter offers, controlling for lottery risk set indicators. P-values are from tests of the hypothesis that all coefficients are zero.

${ }^{*}$ significant at $10 \% ;{ }^{* *}$ significant at $5 \% ;{ }^{* * *}$ significant at $1 \%$ 


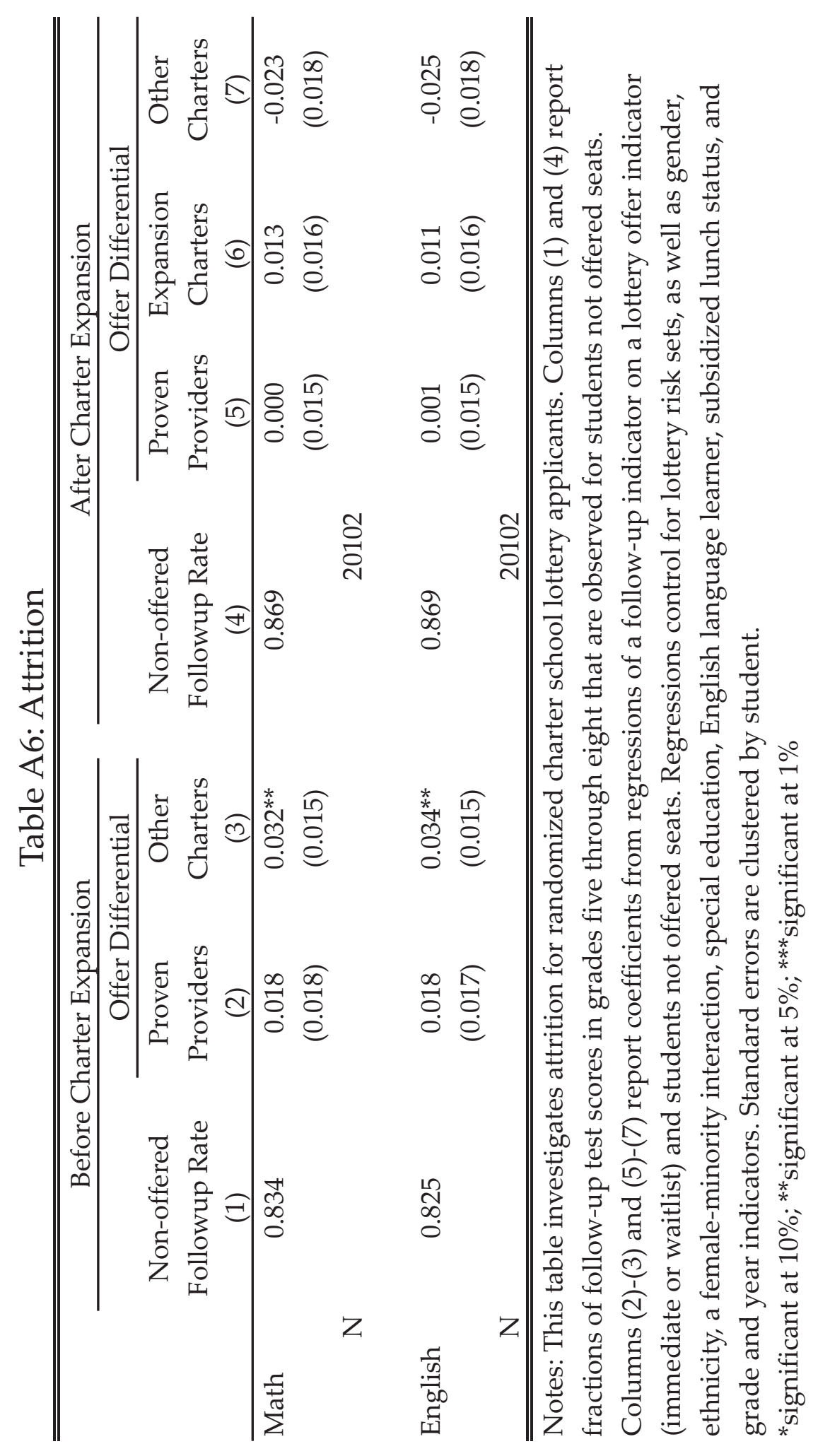




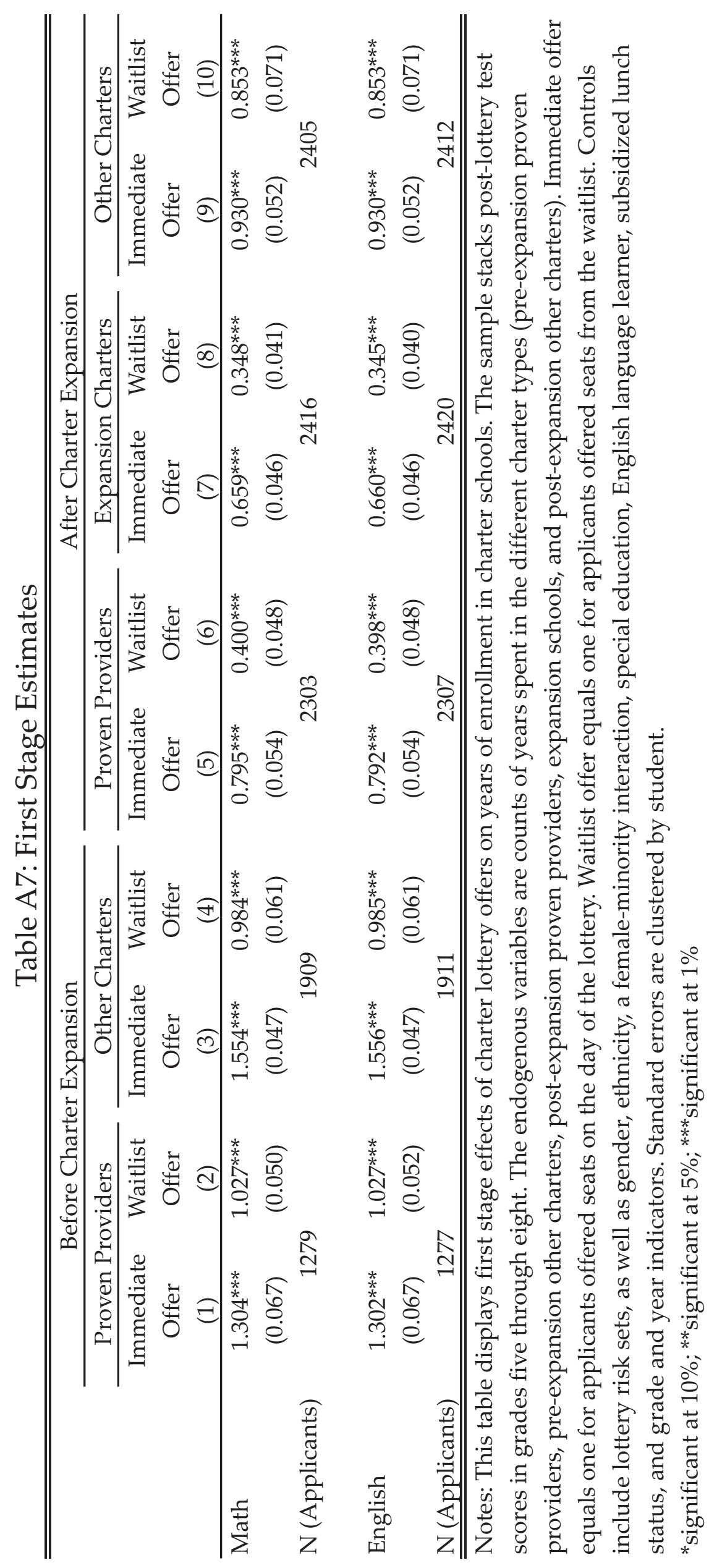




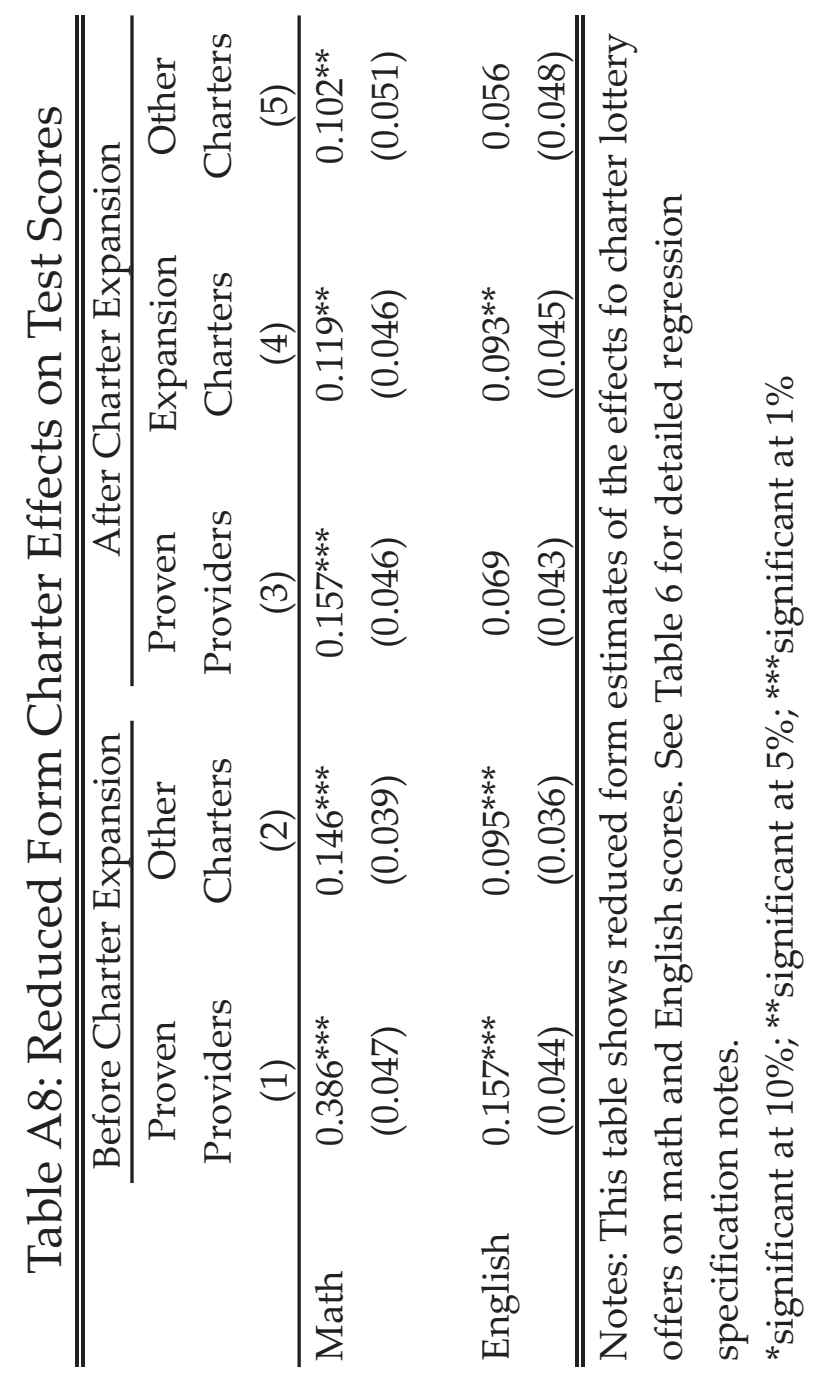




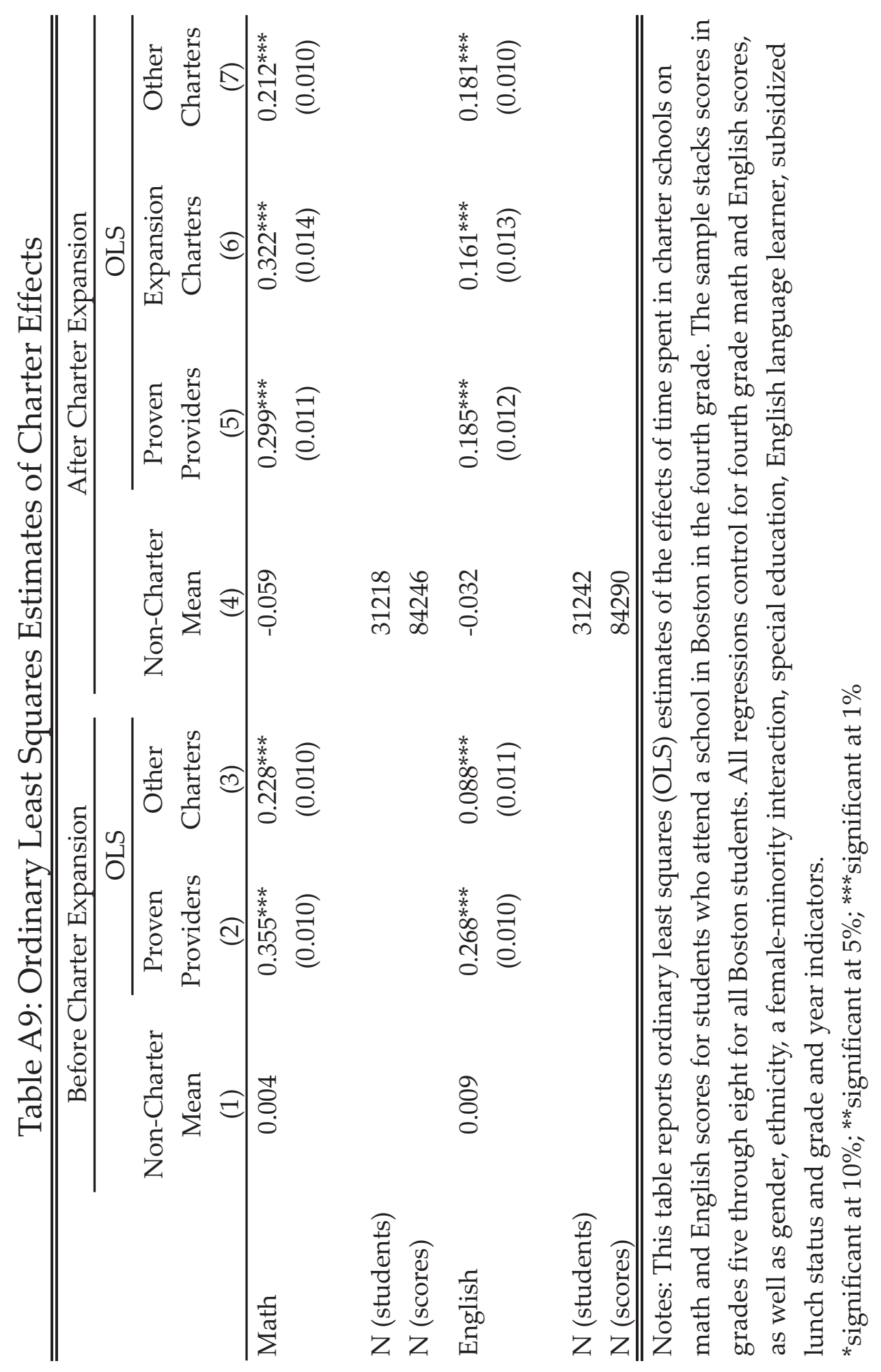




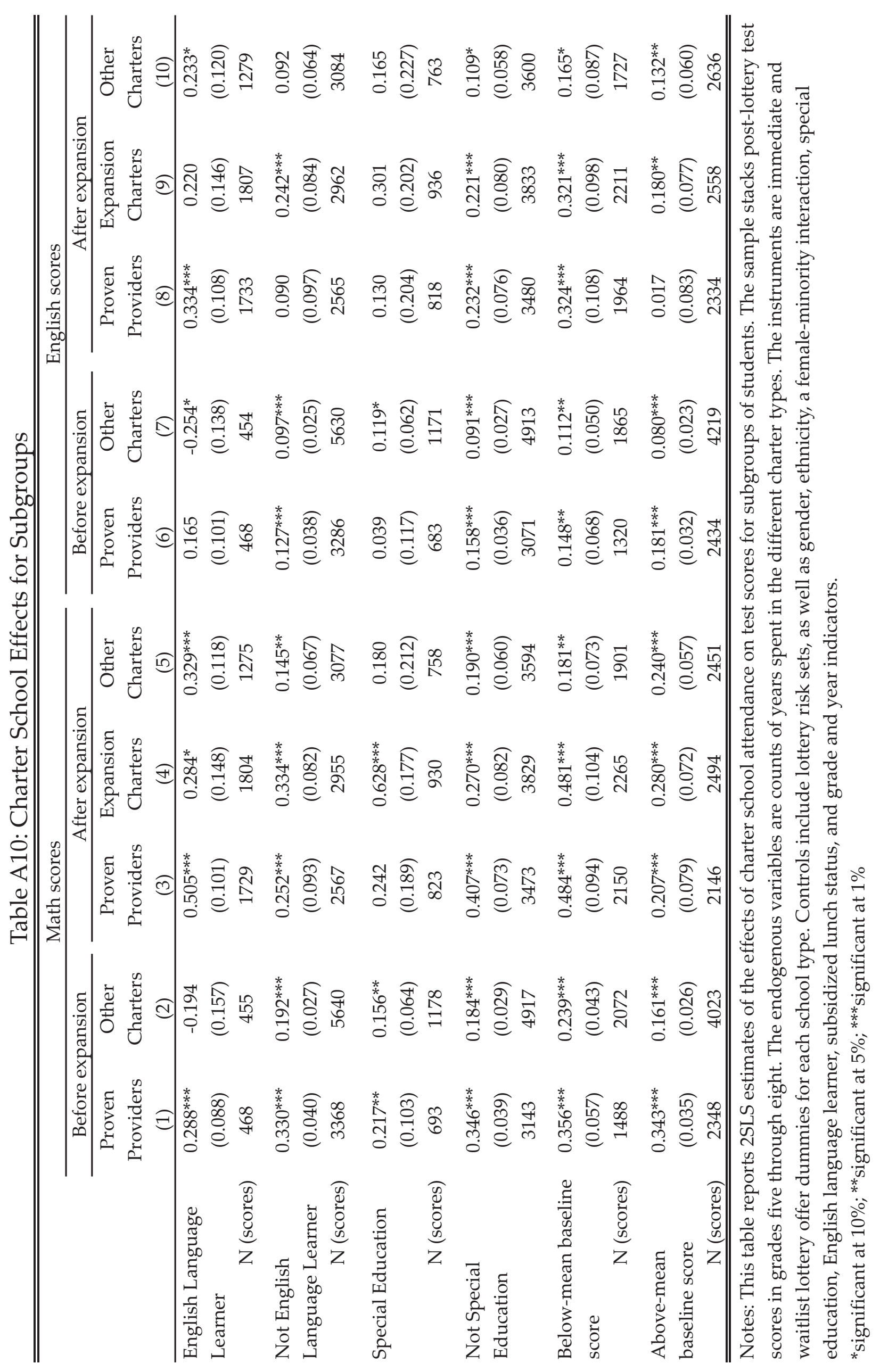

